\title{
INFRAESTRUTURA VERDE-AZUL NA BACIA DO ALTO MANDAQUI: CONECTANDO FRAGMENTOS VERDES ATRAVÉS DO CAMINHO DAS ÁGUAS
}

GREEN-BLUE INFRASTRUCTURE IN THE HIGH MANDAQUI RIVER BASIN: CONNECTING GREEN FRAGMENTS BY THE PATH OF WATERS

\begin{abstract}
JÉSSICA RAGONHA
Mestranda em Arquitetura e Urbanismo pelo IAUUSP, na área de Teoria e História da Arquitetura e do Urbanismo. Residente em Planejamento e Gestão Urbana pela FAUUSP e SMDU-PMSP. jessica.ragonha@usp.br

LíGIA CORRÊA

Arquiteta e Urbanista graduada pela Pontícia Universidade Católica de Campinas (PUC Campinas). ligiacorrea.arquitetura@gmail.com
\end{abstract}

\section{RESUMO}

O presente artigo objetiva apontar meios para se estabelecer uma infraestrutura verdeazul nos bairros cortados pelo córrego do Mandaqui, a partir do caminho dos seus afluentes. O estudo se conforma através da evidenciação de alguns dos córregos ocultos da bacia do Mandaqui, sugerindo de que forma é possível resgatá-los e vinculá-los às áreas verdes existentes e potenciais, tendo a Avenida Caetano Álvares - por onde passa o córrego do Mandaqui canalizado - como eixo principal de uma infraestrutura verde-azul.

Palavras-chave: Infraestrutura verde-azul; Bacia do Mandaqui; córregos ocultos; fragmentos verdes

\section{ABSTRACT}

This article aims to point out the means to establish a blue-green infrastructure in the neighborhoods cut by the Mandaqui Stream, from the path of its tributaries. The study conforms through the disclosure of some of hidden streams of Mandaqui River Basin, suggesting a possible way to rescue and link them to existing and potential green areas, having Caetano Alvares Avenue, where canalized Mandaqui Stream passes through, as the main axis of a blue-green infrastructure.

Keywords: green-blue infrastructure; Mandaqui Basin; hidden streams; green fragments. 


\section{INTRODUÇÃO}

Na cidade de São Paulo, cursos d'água e áreas verdes se fazem presentes na paisagem consolidada de forma tímida, muitas vezes brutalmente sufocados. A poluição e canalização dos rios e córregos é constante e o verde, por sua vez, aparece fragmentado e residual, muitas vezes sem conseguir minimamente atender a uma função social.

Entretanto, observando a malha da cidade com suas áreas verdes e sobrepondo essa à hidrografia, é perceptível que a lógica do caminho das águas atrelada aos espaços verdes existentes revela uma conectividade latente em meio ao tecido urbano. Reconhecer estas potencialidades e regenerar um sistema de áreas verdes é uma alternativa para contribuir com uma cidade mais sustentável e ampliar a relação entre o homem urbano e a natureza, através da viabilização dos serviços ambientais e da promoção de atividades de lazer. Nesse sentido, o conceito de infraestrutura verde aparece como estratégia fundamental para recuperar os fragmentos verdes e cursos d'água obliterados, de forma a conectá-los criando um sistema.

A infraestrutura verde, enquanto rede de espaços verdes conectados, preserva não apenas os processos ecológicos, mas também a qualidade de vida e traz benefícios à população humana. Este artigo busca, então, estudar o conceito de infraestrutura verde como meio de restaurar e conectar as reminiscências dos recursos naturais da bacia do Alto Tietê no tecido urbano consolidado da Zona Norte de São Paulo, resgatando o vínculo entre os fragmentos de áreas verdes e corpos hídricos negligenciados ou suprimidos. Para isso, busca mapear córregos ocultos da bacia do alto Mandaqui e sua relação com as áreas verdes existentes, elegendo como área de estudo os bairros do Mandaqui, Vila Vitorio Mazzei, Jardim Paraíso e Vila Aurora, por onde passam os primeiros afluentes a montante do córrego do Mandaqui.

Em um primeiro momento, o estudo apresenta o processo de consolidação do território urbano de São Paulo na região próxima à Reserva Florestal da Cantareira, apontando os conflitos entre ocupação urbana e preservação ambiental e evidenciando os processos deles decorrentes. Em seguida, introduz a área de estudo e descreve os percursos realizados apontando os vestígios dos córregos na paisagem, procurando revelar a relação destes corpos d'água com as áreas verdes existentes, com a ocupação da área e com os moradores. Posteriormente, discute de que forma é possível resgatar os córregos e vinculá-los às áreas verdes existentes e potenciais, sugerindo 
o conceito de Infraestrutura Verde como possível caminho para se estabelecer uma infraestrutura verde-azul nos bairros cortados pelo córrego do Mandaqui.

\section{OCUPAÇÃO E EXPANSÃO DA ZONA NORTE E SUA RELAÇÃO COM OS RECURSOS NATURAIS}

De acordo com Azis Ab'Saber (2007), a ocupação além-Tietê até o século XIX ocorreu através de pequenos núcleos e povoados no topo das colinas que chegavam até a proximidade da Serra da Cantareira. Naquele momento, a várzea do Tietê separava a região urbana - correspondente à área do centro até a Luz -, da área rural, onde se encontrava a Fazenda de Santana. Santana, o mais antigo núcleo de povoamento da Zona Norte e que deu origem ao bairro do Mandaqui, permaneceu tardiamente com características rurais e, assim, as águas vinculavam-se às atividades econômicas e de recreação.

Segundo Langenbuch (1971), até aproximadamente o ano de 1870, a ocupação urbana da cidade de São Paulo concentrava-se na colina histórica, área de confluência dos rios Anhangabaú e Tamanduateí. As encostas da vertente Sul da Cantareira, por sua vez, estavam situadas em área ocupada pelas plantações de cana-de-açúcar e café. Estas atividades causavam, junto à pecuária e ao extrativismo, a devastação da floresta e, no final do século XIX, a Serra da Cantareira tinha sua cobertura vegetal primária praticamente toda destruída.

Entre os anos de 1870 e 1960 a Floresta da Cantareira passou por um intenso processo de transformação. No contexto da cidade industrial, o Poder Público adquiriu as terras da bacia hidrográfica de mananciais da vertente Sul da Serra da Cantareira para a implantação de uma rede produtora de água potável para a cidade de São Paulo, possibilitando a regeneração da Floresta. Naquele momento foi construída uma pequena estrada de ferro para transportar os materiais necessários à implantação do novo sistema de captação de águas. Tal estrada era servida pelo Tramway da Cantareira, construído em 1893 e operando a partir de 1894, que partia do bairro do Pari - Estação do Tamanduateí - e chegava até o Horto Florestal. As áreas próximas aos ramais do Tramway da Cantareira atraíram a urbanização, com a implantação de núcleos residenciais ao longo de seu caminho e alguns usos comerciais e de serviços próximos às estações e paradas, compondo a expansão da cidade para essas áreas mais periféricas. A chegada de melhoramentos à região intensificou o processo de 
ocupação das várzeas dos rios, e os moradores mais próximos às margens viram-se diante dos problemas de cheias e concentração de entulhos. Ao final da década de 30, a chegada do ônibus foi substituindo as viagens realizadas pelo Tramway da Cantareira. Locais antes isolados passaram a se desenvolver e novos loteamentos residenciais foram se estabelecendo na Zona Norte, mas o padrão de ocupação periférica com ausência de infraestrutura foi mantido (HERLING, 2002).

As primeiras intenções de retificação do rio Tietê surgiram no final do século XIX e as obras foram iniciadas apenas em 1938. O trecho deste rio mais próximo à Bacia do Mandaqui foi canalizado na década de 1940 e, nesse processo, surgiam novas possibilidades de ocupação das margens dos rios e de construção de vias marginais. A partir da década de 1950, o traçado dos rios afluentes da margem direita do Rio Tietê foi sendo alterado. $O$ traçado sinuoso passou a ser retificado para a implantação de avenidas de fundo de vale, no processo de expansão urbana periférica (HERLING, 2002).

A partir dos anos 1960, os recursos hídricos e vegetais passaram por um novo modelo de exploração para a produção de água potável, sobretudo em função do crescimento da atividade industrial. Criada em 1973, a SABESP (Companhia de Saneamento Básico do Estado de São Paulo) implementou um novo sistema produtor de água potável e o Sistema Produtor da Cantareira passou a captar água de bacias cada vez mais distantes, provenientes do norte da Serra da Cantareira. A captação de águas em áreas não protegidas pela Reserva Florestal da Cantareira fez com que a Floresta perdesse sua função econômica diretamente vinculada à infraestrutura urbana; assim, as águas foram desvinculadas da proteção da floresta e de seu caminho natural na bacia hidrográfica, de acordo com Herling (2002). A exploração dos recursos hídricos foi se caracterizando por sistemas desarticulados entre si, sem a preocupação de buscar a renovação dos recursos explorados e gerando dificuldades de recuperação e manutenção do sistema. Nesse momento, cada vez mais a paisagem natural foi sofrendo transformações em função da crescente supressão de seus recursos para a implantação de obras de infraestrutura.

A cidade de São Paulo permaneceu crescendo segundo a lógica rodoviarista, com incentivos à construção de avenidas de fundo de vale, sobretudo entre as décadas de 1970 e 1990. Cada vez mais o desenho da cidade deixou de incorporar os cursos d'água como elementos de sua paisagem, e passou a dominá-los ou ocultá-los, em um intenso processo de afastamento do convívio das pessoas junto a esses espaços. 
Na década de 1970 teve início a canalização do Córrego Mandaqui, em cujo canal se construiu a avenida de fundo de vale Av. Engenheiro Caetano Álvares, conectando a Avenida Marginal Tietê ao bairro Tremembé. Este curso d'água se encontra enterrado na maior parte da extensão da avenida e na parte final sua canalização é em seção retangular de concreto, a céu aberto, com vigas estroncas (MONTEIRO JUNIOR, 2011), tornando as relações com os rios e córregos cada vez mais distantes. Muitos de seus afluentes também passaram por esse mesmo processo de canalização e tamponamento. Alguns trechos permaneceram visíveis e, no entanto, igualmente desassociados do desenho urbano. Assim, os rios e córregos, inicialmente fundamentais ao desenvolvimento da região, foram se tornando barreiras ao seu crescimento e ocupação. A solução encontrada foi, então, suprimi-los e escondê-los na paisagem.

A relação de apropriação dos recursos naturais se torna cada vez mais evidente nos constantes processos de expulsão da população pobre para as áreas periféricas e de proteção ambiental. Ocupações desordenadas e informais revelam fortes impactos na paisagem e agravam os problemas ambientais, avançando em terrenos cada vez mais frágeis e a legislação ambiental torna-se insuficiente de proteger essas áreas. Nesse processo, a ocupação urbana se espraia sem controle em direção às matrizes naturais, o que ameaça a preservação das florestas e dos recursos hídricos.

A ameaça aos recursos naturais não se dá apenas por uma questão habitacional, mas também pelo desenvolvimento da infraestrutura viária, como exemplo a implantação do último trecho do Rodoanel na Zona Norte junto à Cantareira. Antes do início da obra, em 2013, ambientalistas tentaram impedir seu financiamento em função dos danos ambientais e sociais, tendo sido previsto o deslocamento de até 20 mil pessoas. Segundo a Dersa (2013), a rodovia será construída a jusante dos mananciais e passará por baixo do Parque da Serra da Canteira através de túneis, e a supressão de vegetação - aprovada pela CETESB e anuída pelo Ibama - será da ordem de 120 hectares. A compensação será feita através do plantio de 1,6 milhão de espécies nativas em uma área de 1000 hectares, entretanto é previsto o corte, pela rodovia, de 16 parques ou áreas verdes consolidadas, um contingente verde e de biodiversidade que leva anos para se reestabelecer.

\section{A ÁREA DE ESTUdO E O LEVANTAMENTO DOS CORPOS HÍDRICOS}

Para estudar o vínculo entre os fragmentos de áreas verdes e corpos hídricos, negligenciados ou suprimidos, decorrente da ocupação da Zona Norte, foi definido como 
objeto a Bacia do Córrego Mandaqui, cuja nascente está localizada na Invernada da Polícia Militar. Como recorte, delimitou-se a área a montante do curso d'água, entre a Rua Voluntários da Pátria e a Invernada Militar ao norte.

O córrego Mandaqui fez parte do Programa Córrego Limpo - parceria entre SABESP, Governo de São Paulo e Prefeitura Municipal de São Paulo - para promover a despoluição dos córregos do Estado. O Programa teve início em 2007, e o córrego Mandaqui encontrava-se em situação alarmante com alta concentração de poluentes, entulho e esgotos (TZORTZIS; KNIESS, 2015). Além do intenso mau cheiro, a água do córrego mantinha aparência turva (Fig.1), mas houve melhora significativa de suas condições após o serviço de despoluição (Fig.2). Entretanto, alguns trechos do córrego e de seus afluentes revelam hoje a situação de poluição, descarte de lixo e lançamento de esgoto sem tratamento, reproduzindo os problemas contra os quais o Programa lutou para reverter.

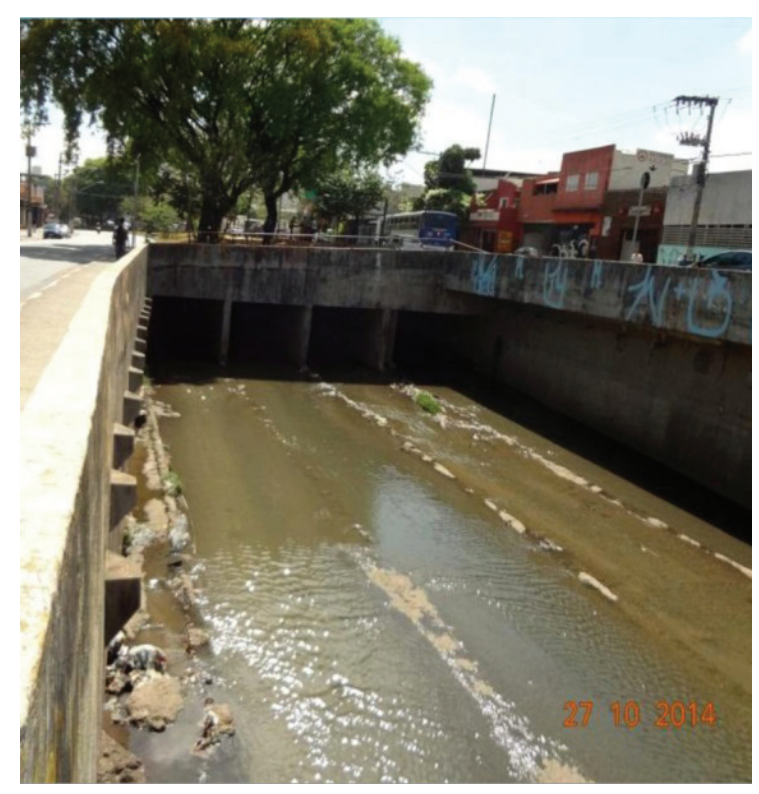

Figura 1 - Córrego Mandaqui antes do Programa Córrego Limpo. Imagem de abril de 2011. Fonte: SABESP (s.d.).

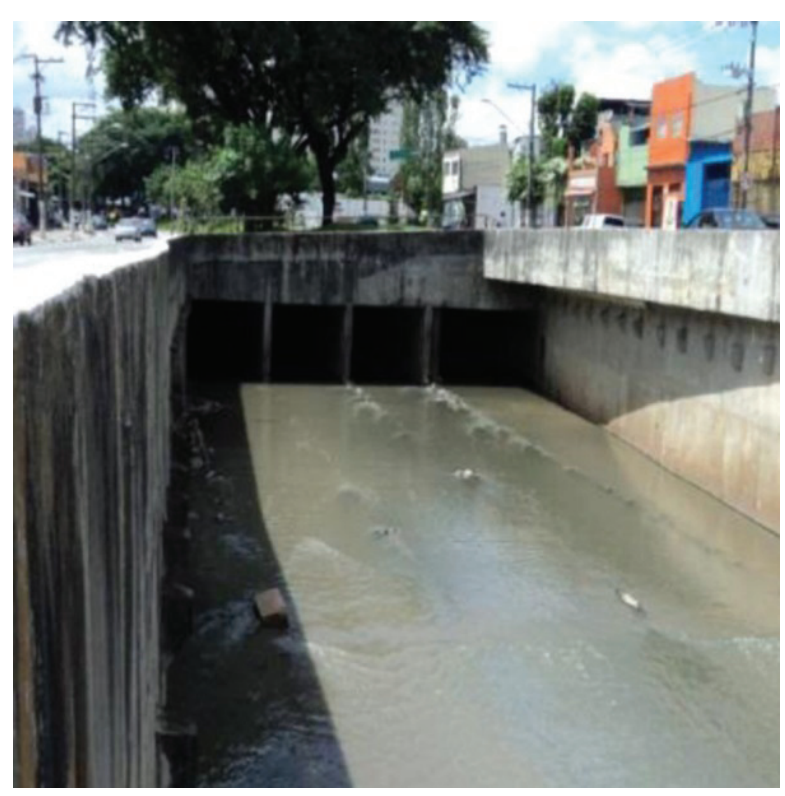

Figura 2 - Córrego Mandaqui depois do Programa Córrego Limpo. Imagem de outubro de 2014. Fonte: SABESP (s.d.).

A canalização do córrego Mandaqui seguiu o padrão repetido em toda a cidade de São Paulo, com o intuito de reduzir as enchentes e melhorar as questões de coleta de esgoto. No entanto, esse processo causa danos ambientais e traz uma série de problemas por alterar o curso natural dos rios e impermeabilizar o solo. A atual situa- 
ção é bastante preocupante, pois ora os rios e córregos sequer se revelam na paisagem, ora aparecem como destino de lixo ou do lançamento de esgoto sem tratamento, criando uma condição insalubre de canal de esgoto a céu aberto. Como aponta Cabral (2015) sobre a Avenida Engenheiro Caetano Álvares:

\begin{abstract}
A exemplo de muitas outras vias e espaços livres das grandes cidades brasileiras, a avenida mencionada resulta de intervenções realizadas ao longo da consolidação do espaço urbano que incidiram diretamente sobre cursos d'água. Suprimindo os córregos enquanto elementos abrangidos por uma noção de paisagem ou transformando profundamente suas feições, tais intervenções respondem de maneira bastante peculiar a certas demandas das cidades contemporâneas - relacionadas à mobilidade, à drenagem urbana, aos sistemas de saneamento. A peculiaridade do intervir em tais elementos reside, justamente, no fato de que, por mais invasiva que seja a operação empreendida pelo fazer humano, há certos aspectos dos cursos d'água e de sua conformidade que parecem resistir ao seu ocultamento, manifestando-se à superfície nos entreatos do espaço urbano. (CABRAL, 2015)
\end{abstract}

Ainda segundo Cabral (2015), ao se caminhar pela avenida é praticamente inacessível à consciência o fato de que se está sobre o leito tamponado do córrego Mandaqui e imaginar que existem diversos córregos menores que nele deságuam sob a superfície. Entretanto, ao debruçar-se sobre um mapa da Zona Norte é notável a ocorrência de diversos fragmentos de áreas verdes nas proximidades da Avenida Caetano Álvares, e ao sobrepor a esse mapa o mapa hidrográfico, é possível estabelecer relações entre estas áreas verdes e o caminho das águas.

Partindo desta sobreposição foram estabelecidos seis trajetos, cada um correspondendo a um corpo d'água levantado, sendo três para cada uma das vertentes do Mandaqui. O objetivo é entender o caminho que estas águas aprisionadas fazem hoje e, através de seus resquícios, investigar sua relação com a ocupação urbana e os fragmentos verdes que conformam espaços verdes públicos. Tal análise fomenta a avaliação de possíveis estratégias de Infraestrutura Verde para recuperação dos corpos hídricos e a sistematização de áreas verdes. Para compreender esta relação no tempo, foram levantados os mapas da SARA Brasil (Società Anonima di Rilevamenti Aerofotogrammetrici), que documentam a São Paulo de 1930, fornecendo informações importantes sobre a ocupação urbana e topografia da época. 


\subsection{PERCURSOS}

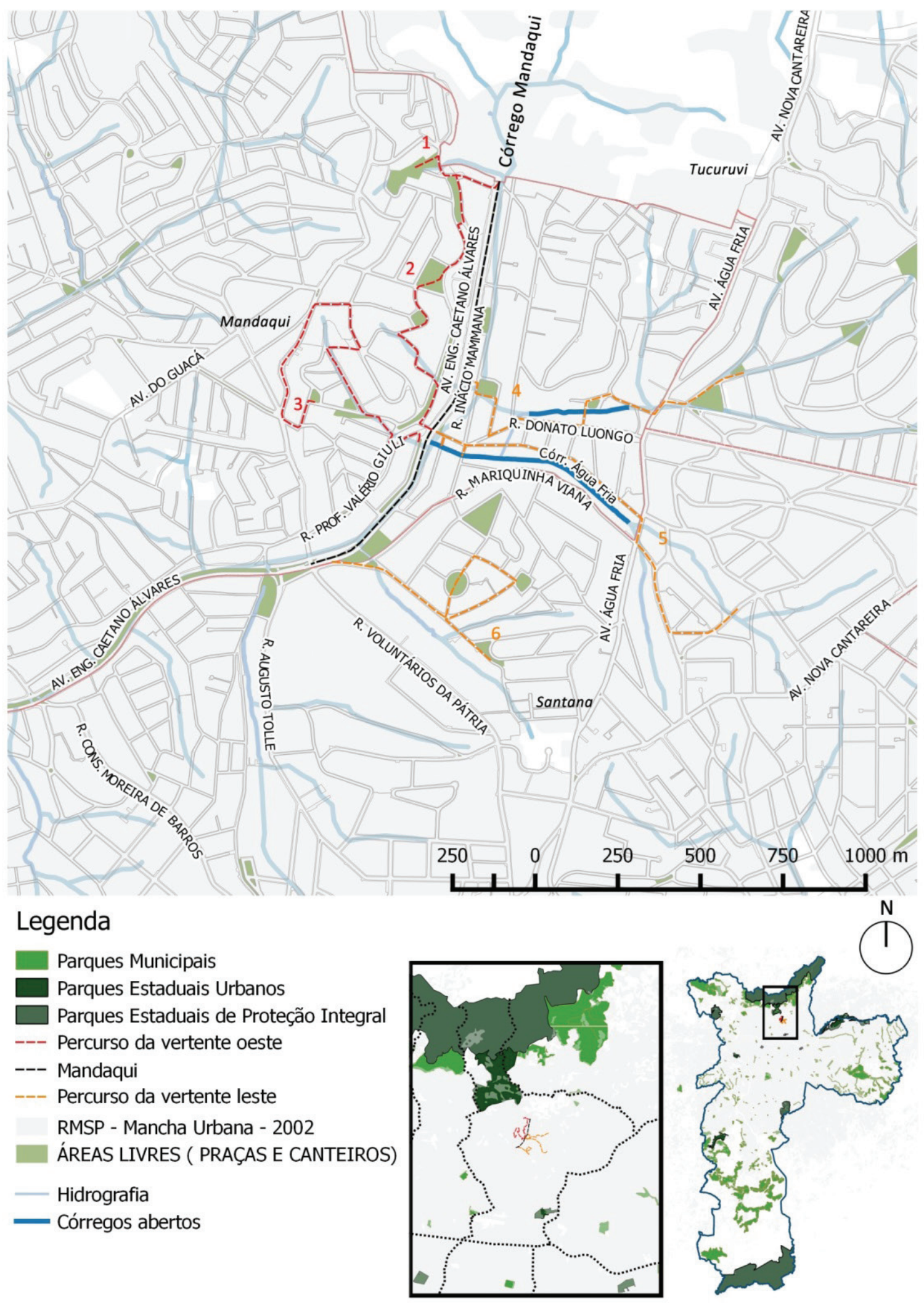

Figura 3 - Mapa com indicação dos percursos. Desenvolvido pelas autoras. Fonte: SMDU. 


\subsubsection{VERTENTE OESTE}

A vertente oeste do córrego Mandaqui é marcada por afluentes considerados como veios d'água. No mapeamento de 1930, estes veios somente aparecem como linhas de drenagem.

\section{Percurso 1 - Veio d’água}

Partindo-se da nascente do córrego Mandaqui, localizada na Invernada da Polícia Militar, e seguindo pela Rua Irmão João Creff, chega-se à Praça Dom Francisco Xavier

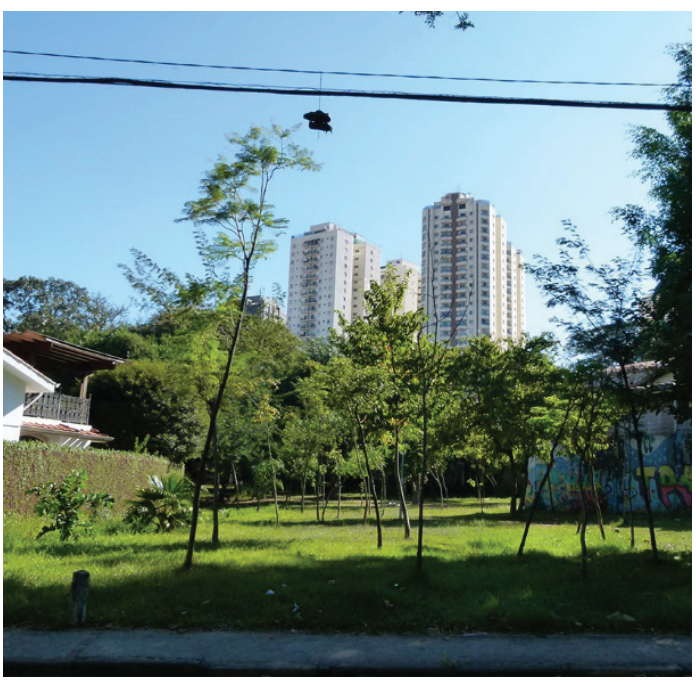

Figura 4 - Praça Dom Francisco Xavier Aranha. Fonte: Imagem das autoras, 2016.

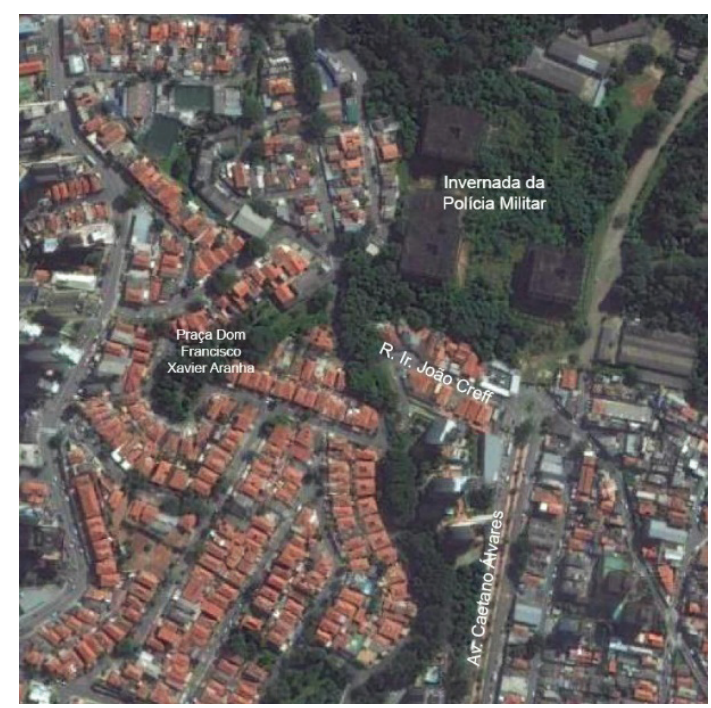

Figura 5 - Fonte: Google Earth, 2016.
Aranha. Esta praça se configura exatamente sobre o veio d'água, seguindo o traçado sugerido pelo mapa de hidrografia, mas não existem vestígios do mesmo.

As edificações ao redor, que se dispõem num desenho irregular decorrente da linha de drenagem, viram os fundos para a praça delimitando-a com seus muros de divisa. É um espaço amplo e arborizado, porém residual e sem equipamentos ou pavimentação expressiva, inserindo-se na paisagem como elemento negligenciado (Fig.4).

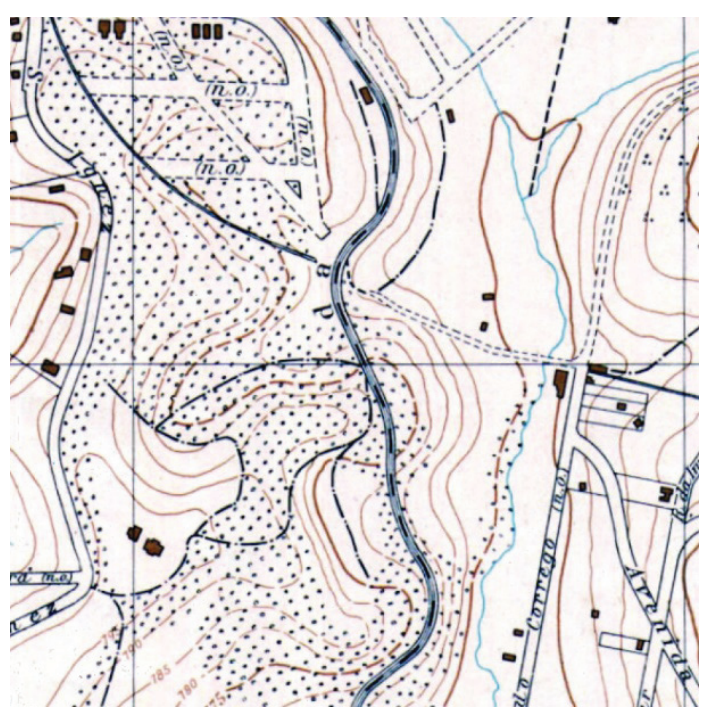

Figura 6 - Fonte: SARA Brasil, 1930. 
É notável, através do mapa da SARA Brasil (Fig.6), que a Praça Dom Francisco Xavier Aranha (Fig.5) corresponde ao que, em 1930, era uma linha de drenagem. A ocupação nesse trecho se configurou em torno dela, com o arruamento acompanhando a topografia do terreno.

\section{Percurso 2 - Veio d'água}

Este percurso na vertente oeste do córrego do Mandaqui se inicia seguindo a Rua General Nestor Passos e subindo pela Rua Padre Rosser. A hidrografia sugere que o córrego deve estar canalizado sob a Rua Padre Rosser, e uma evidência se revela na paisagem: uma grade através da qual se observa uma área verde é o indício da passagem do córrego neste trecho. Continuando o caminho e seguindo pela Rua Cosme da Costa, chega-se à Praça Ademar Noronha Nogueira, muito próxima à Praça Agostinho Gianotti, sendo as duas conectadas pela Rua Setsuo Yazaki. A Praça Agostinho Gianotti, bastante arborizada, conecta-se a uma área verde linear que se conforma sobre um talude alto e extenso até a Invernada da Polícia Militar, em área bastante íngreme, junto à Rua General Nestor Passos (Fig.7).

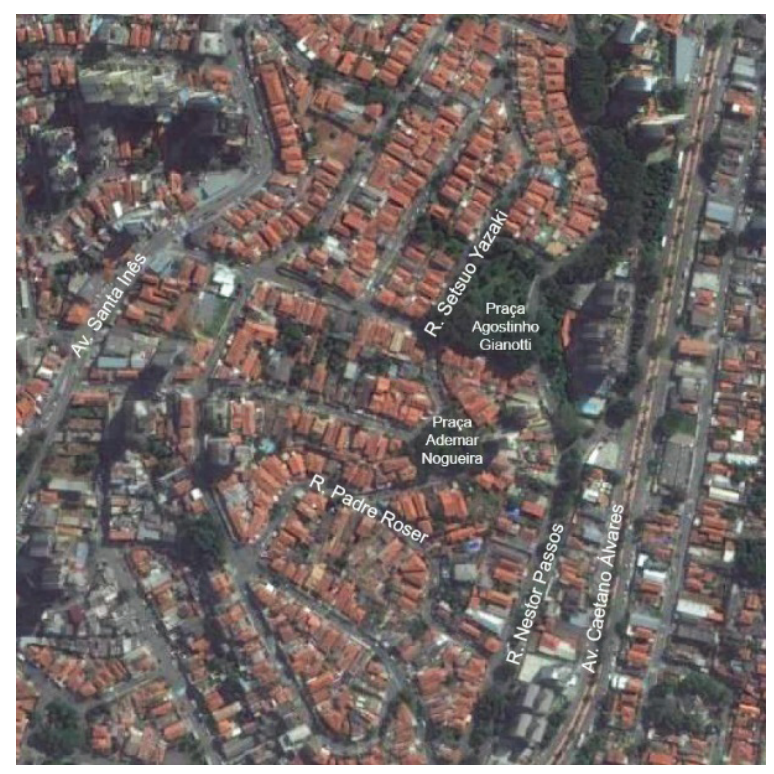

Figura 7 - Fonte: Google Earth, 2016.

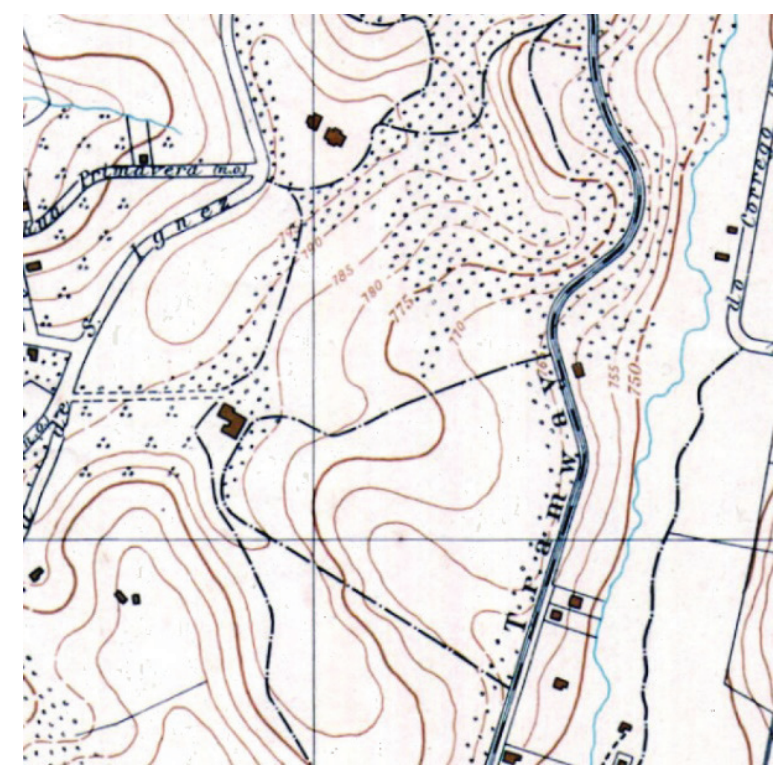

Figura 8 - Fonte: SARA Brasil, 1930.

Através do mapa da SARA Brasil (Fig.8), pode-se observar que o Tramway da Cantareira passava onde hoje existe a Rua General Nestor Passos, e que a declividade do 
talude protegeu a vegetação que permanece até hoje. A ocupação nas proximidades da linha do Tramway segue o desenho da topografia.

\section{Percurso 3 - Veio d'água}

O percurso se iniciou na Rua André Domingues, na Praça Artur Pederzoli. Caminhase até o cruzamento entre a Rua Voluntários da Pátria e a Avenida Santa Inês, pela qual se segue. Esta avenida, importante na região, carece de áreas verdes e espaços qualificados para o pedestre. A partir dela entra-se na Rua Engenheiro Jean Buff, de onde é possível observar pelos portões das casas o declive acentuado do terreno, que evidencia o caminho das águas. Através do mapa da SARA Brasil (Fig.10), podese inferir que a topografia bastante irregular foi pouco modificada no processo de ocupação (Fig.9).

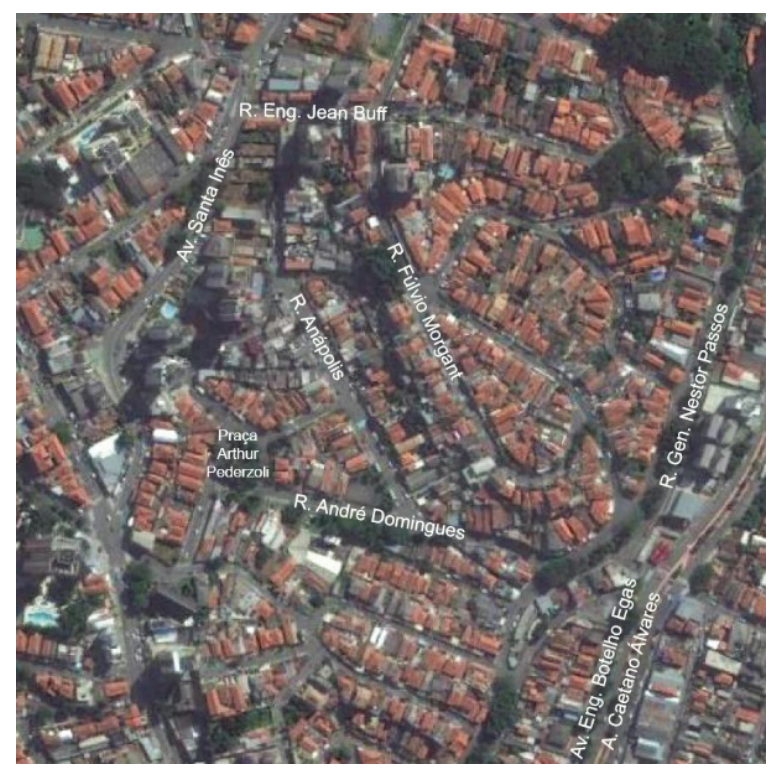

Figura 9 - Fonte: Google Earth, 2016.

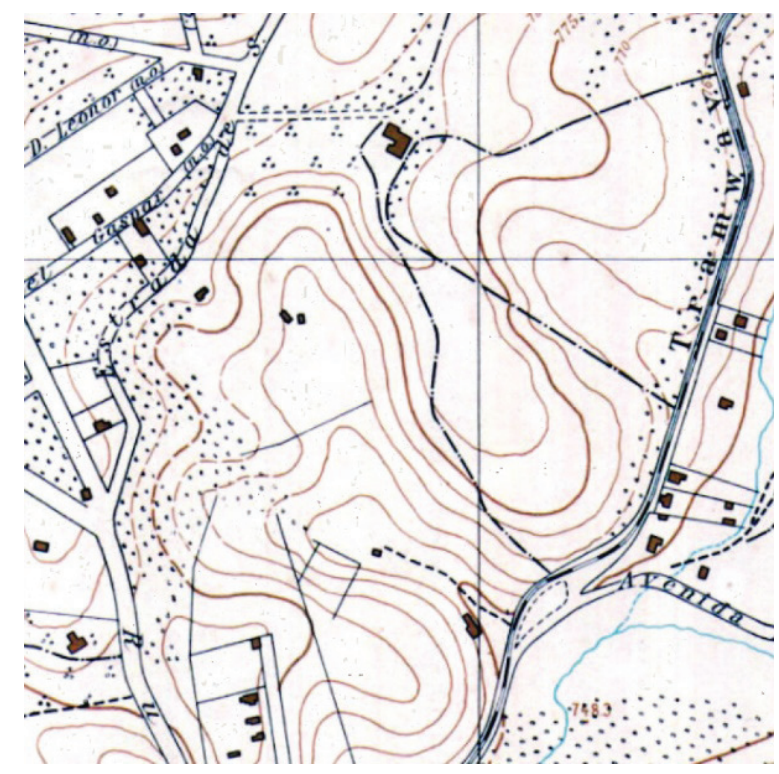

Figura 10 - Fonte: SARA Brasil, 1930.

Contornando o trajeto deste córrego, seguiu-se pela Rua Fúlvio Morgant onde se abre um percurso arborizado de escadas (Fig.11) que descem o relevo íngreme até encontrar a Rua Anápolis (Fig.12). 


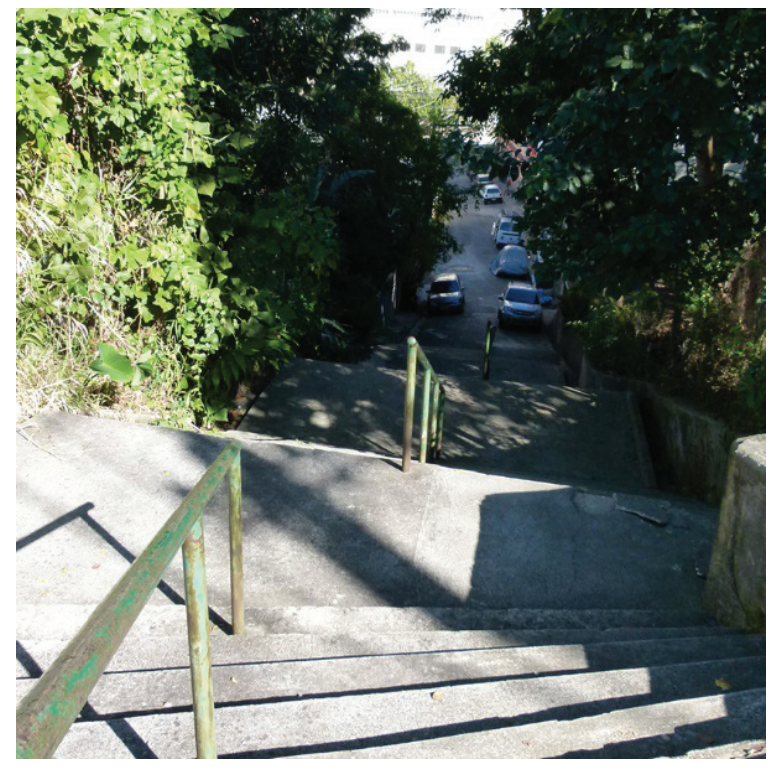

Figura 11 - Escadaria que leva até a R. Anápolis. Fonte: Imagem das autoras, 2016.

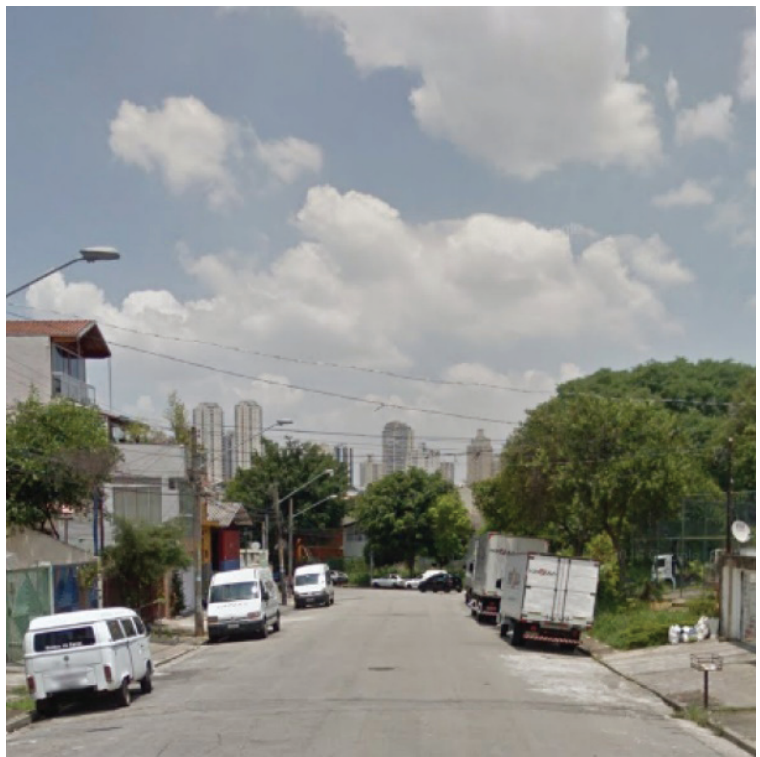

Figura 12 - Rua Anápolis. Fonte: Google Earth 2016.

Segue-se até o encontro com a Rua André Domingues, onde se configura um "nó" de áreas verdes públicas associado ao caminho do córrego: uma quadra pública (Fig.13) e frente a ela um espaço verde residual (Fig.14) que cobre o aclive até a praça Artur Pederzoli.

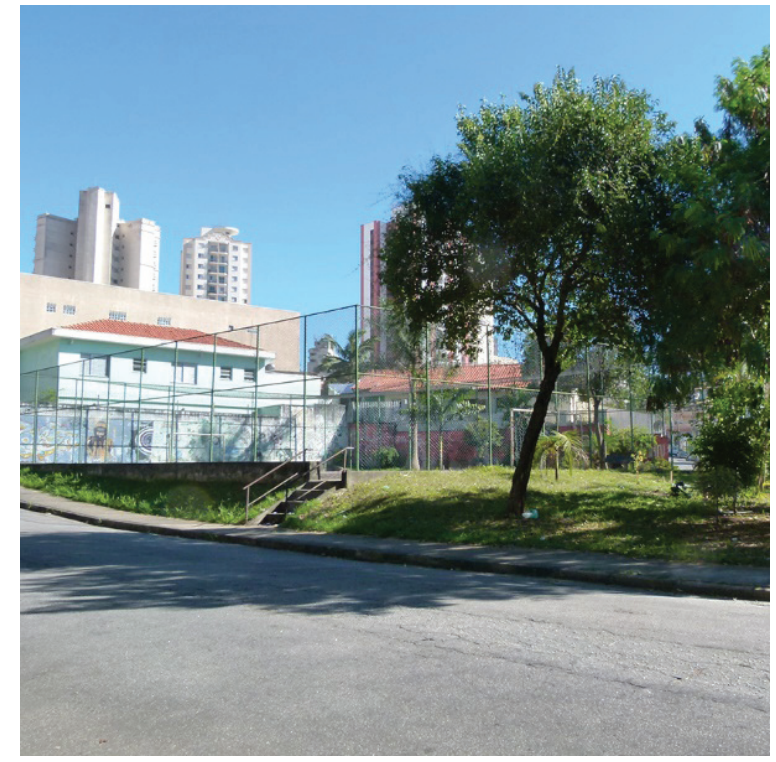

Figura 13 - Quadra pública na Rua André Domingues. Fonte: Imagem das autoras, 2016.

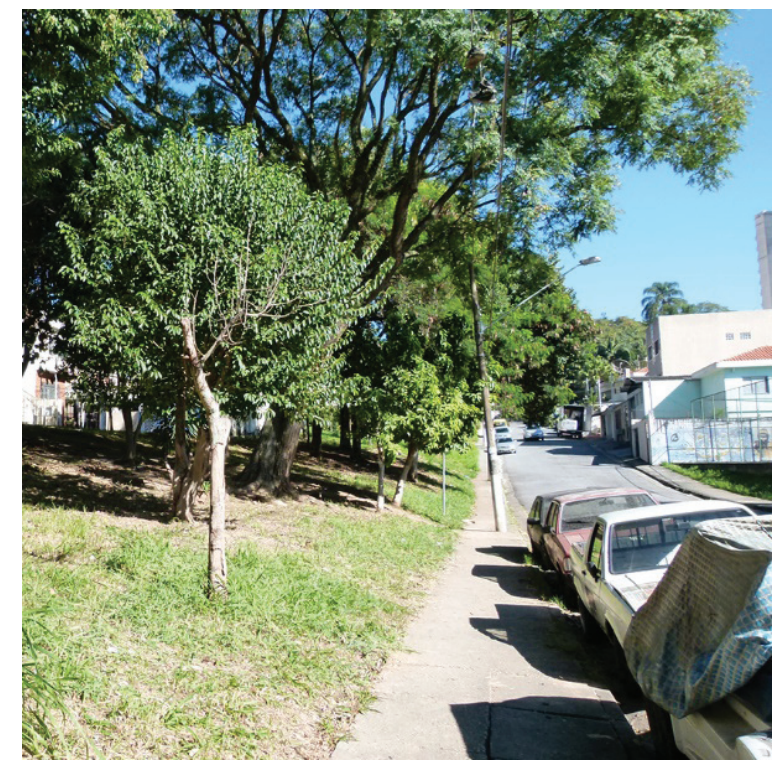

Figura 14 - Espaço verde residual na R. André Domingues. Fonte: Imagem das autoras, 2016. 


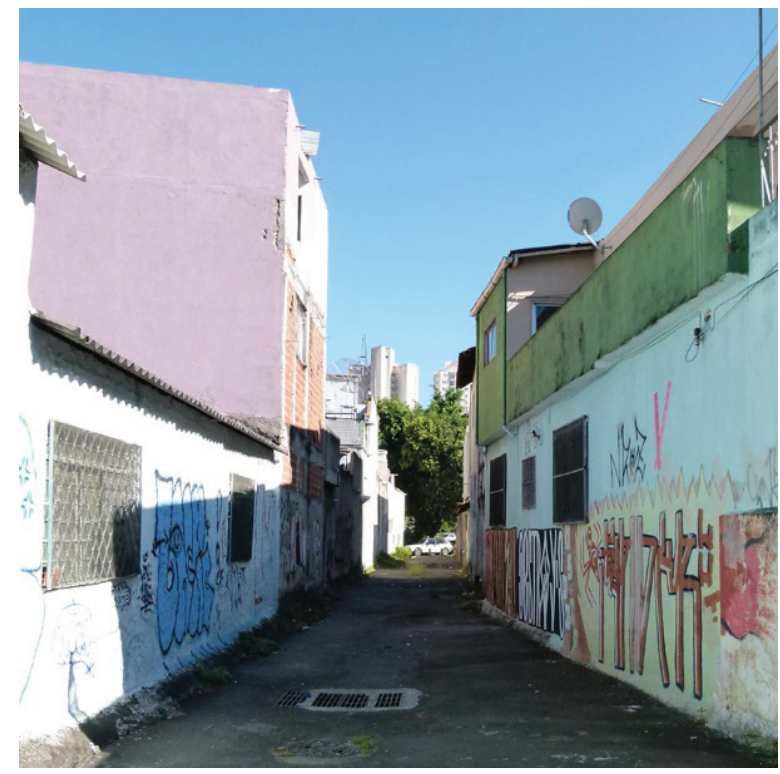

Figura 15 - Vista da Viela. Fonte: Imagem das autoras, 2016.
Mais adiante se evidenciam indícios da passagem do córrego: uma viela (Fig.15) se abre entre as edificações, como um corte no tecido urbano, uma cicatriz resultante do sistema de escoamento das águas (Fig.16 e 17). Nela pode-se observar uma grelha como sinal da canalização e a presença de vegetação rasteira, que cresce pelas fendas do concreto.

As casas abrem suas janelas para a viela, sendo que uma delas também abre uma porta, acessada através de degraus. As paredes da viela são desenhadas por graffiti. Um espaço de passagem; uma memória debaixo do chão que guarda consigo elementos do passado. A conformação desta viela sugere que o córrego tenha sido canalizado e tamponado há bastante tempo, tendo os moradores das casas contíguas se apropriado desse espaço para ampliá-las até os limites de seus terrenos, uma vez foi possível abri-las para a viela.

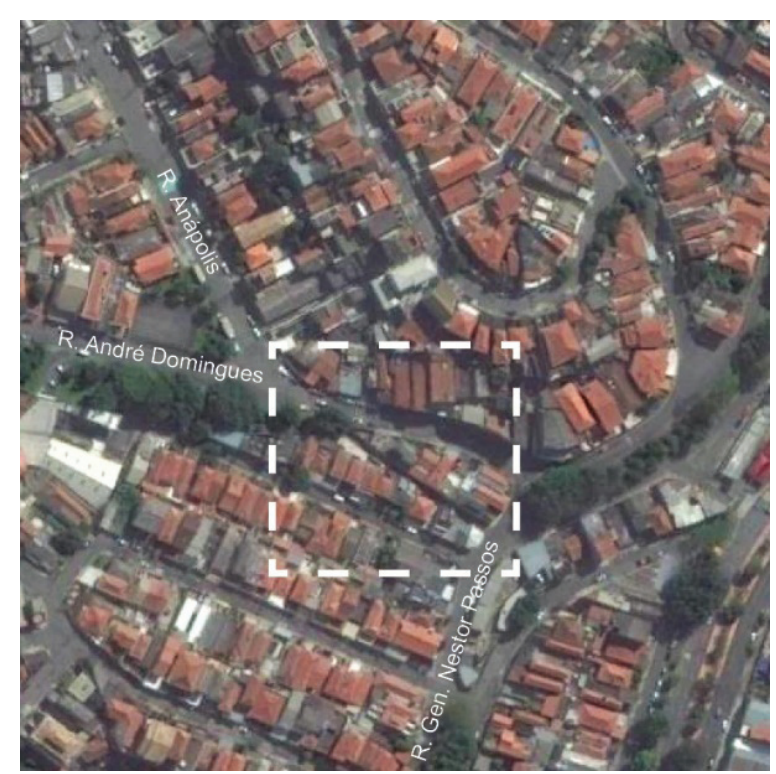

Figura 16 - Viela como cicatriz no tecido urbano. Fonte: Google Earth, 2016.

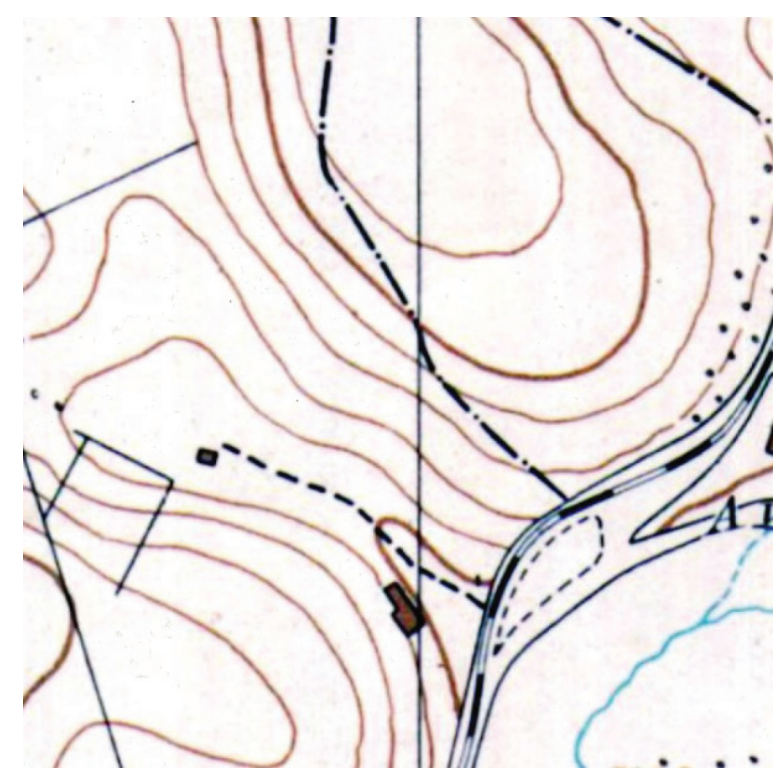

Figura 17 - Linha de drenagem correspondente ao veio d'água por onde passa a viela. Fonte: SARA Brasil, 1930. 
A partir daí segue-se em direção à Av. Engenheiro Botelho Egas, que se coloca paralelo à Av. Engenheiro Caetano Álvares. Ali a passagem do córrego se faz evidente pelo som: uma boca-de-lobo revela sua existência através do barulho constante do curso d'água.

\subsubsection{VERTENTE OESTE}

Dentro do perímetro da área de estudo, é possível observar no mapeamento de 1930 que a vertente leste alimenta o Córrego Mandaqui com dois afluentes. Hoje, no entanto, com a topografia severamente alterada em sua margem, pode-se detectar que o primeiro afluente a montante se dividiu em dois córregos, um anônimo, mais a montante, e o da Água Fria, totalizando em três córregos a serem levantados.

\section{Percurso 4 - Córrego anônimo}

O primeiro córrego, anônimo, deságua oculto no Mandaqui, sendo que seu único vestígio talvez seja uma área verde pertencente a uma escola. O curso d'água segue canalizado e tamponado pelo meio dos quarteirões se abre à paisagem em meio ao quarteirão conformado pela R. João de Laet, Rua Donato Longo e Travessa Pascoal Presto. O trecho descrito pode ser observado em imagem atual (Fig.18) e no mapa de 1930 (Fig.19).

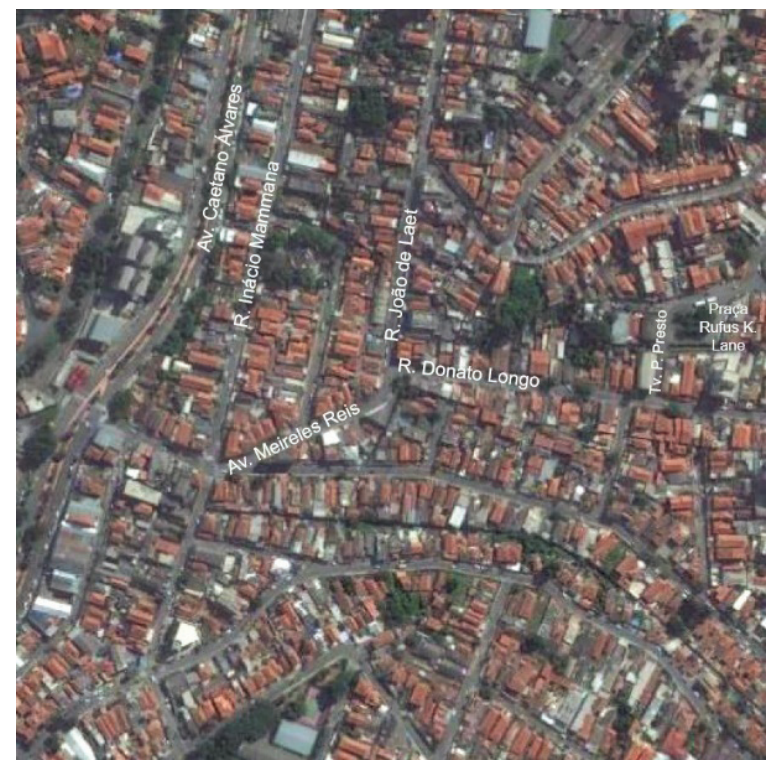

Figura 18 - Fonte: Google Earth, 2016.

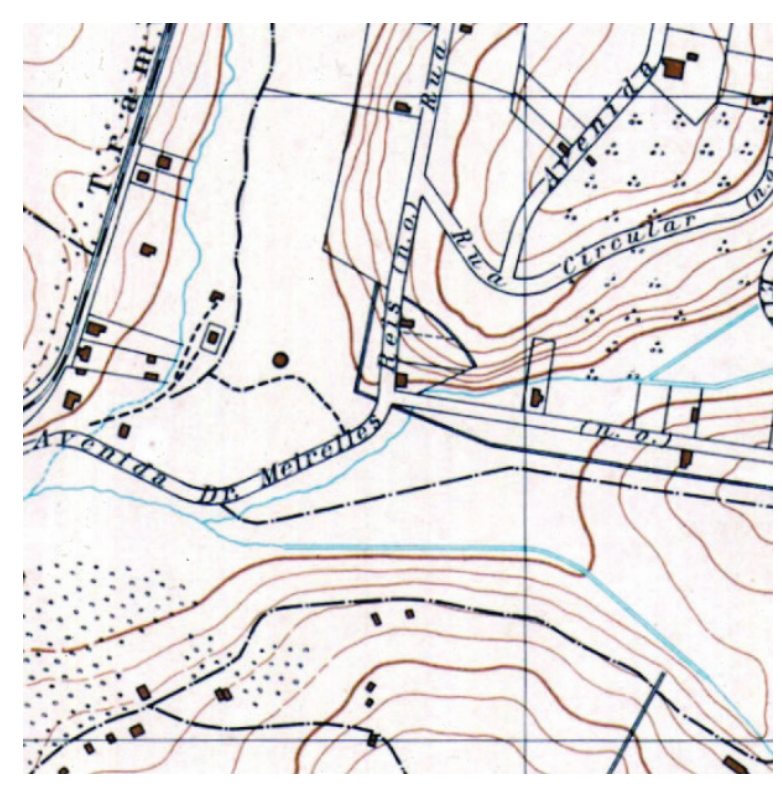

Figura 19 - Fonte: SARA Brasil, 1930. 
O fundo das casas se abre para sua passagem e num ponto da Travessa é possível visualizá-lo: um ponto de surpresa, com a passagem das águas por entre os muros das casas da quadra entre as ruas Donato Longo e João de Laet, onde o odor é quase imperceptível e existem uma vegetação desenvolvida, atraindo pássaros e criando uma situação menos distanciadora, embora ainda seja visível algum descarte de lixo (Fig.20). No trecho da passagem do córrego mais ao meio do quarteirão existe uma considerável área verde murada.

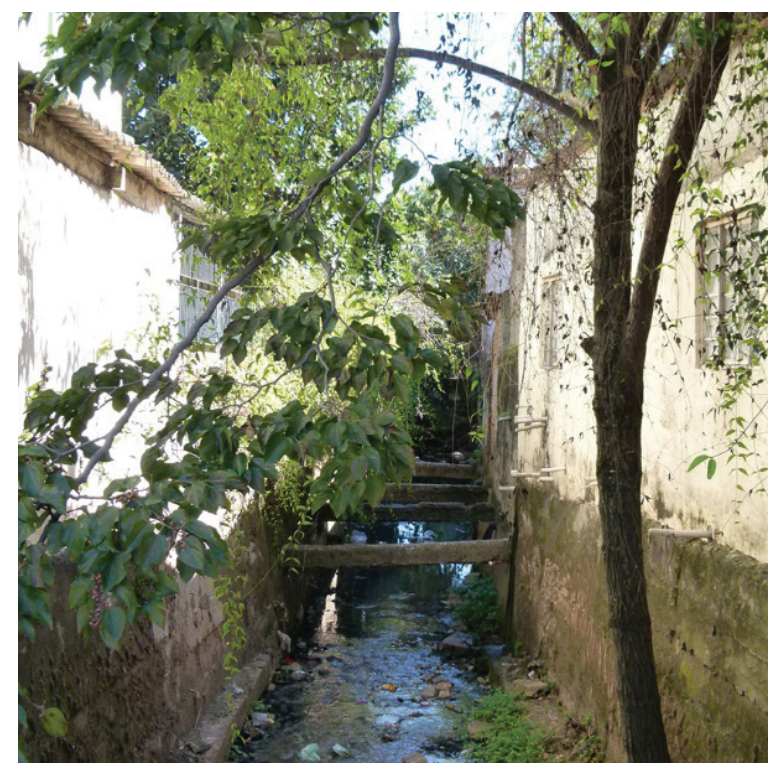

Figura 20 - Córrego entre muros de divisa, paralelo a R. Donato Longo. Fonte: Imagem das autoras, 2016.

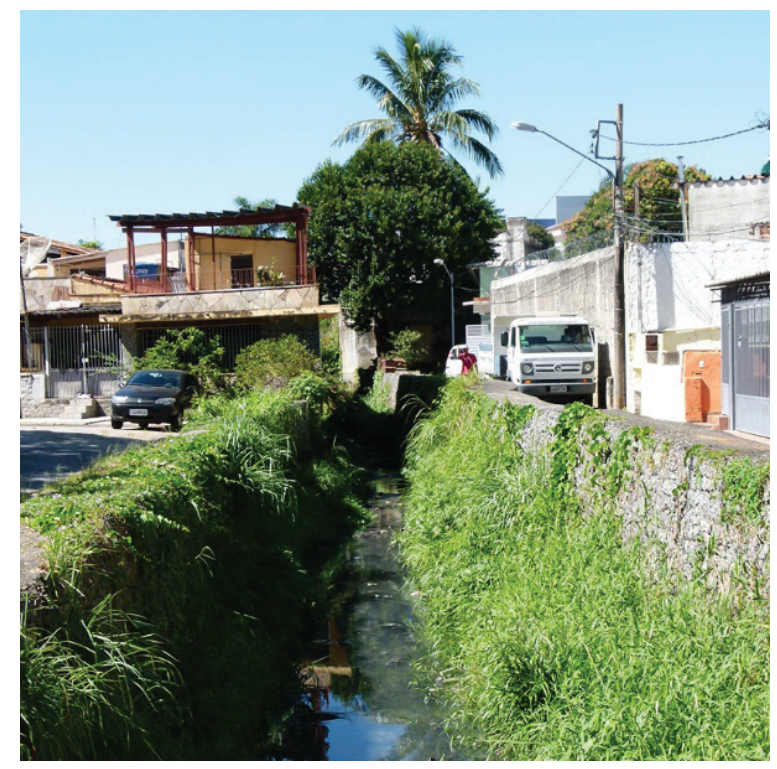

Figura 21 - Córrego entre muros de pedra ao lado da Praça Rufus King Lane. Fonte: Imagem das autoras, 2016.

O córrego segue aberto pelo outro lado da Travessa Pascoal Presto, agora entre muros de pedra (Fig.21) junto à Travessa Rufus King Lane, onde uma área verde se faz presente enquanto Praça Rufus King Lane (Fig.22). É notável nesse ponto que a presença de tal praça junto à passagem do curso d'água configura uma situação única da na área levantada: ele participa, ainda que de forma negligenciada, agradavelmente da conformação de uma área verde pública. É sensível então a qualidade de um curso d'água quando associado à área verde, e seu potencial fica evidente mesmo em uma área pública na qual os investimentos são insuficientes. 


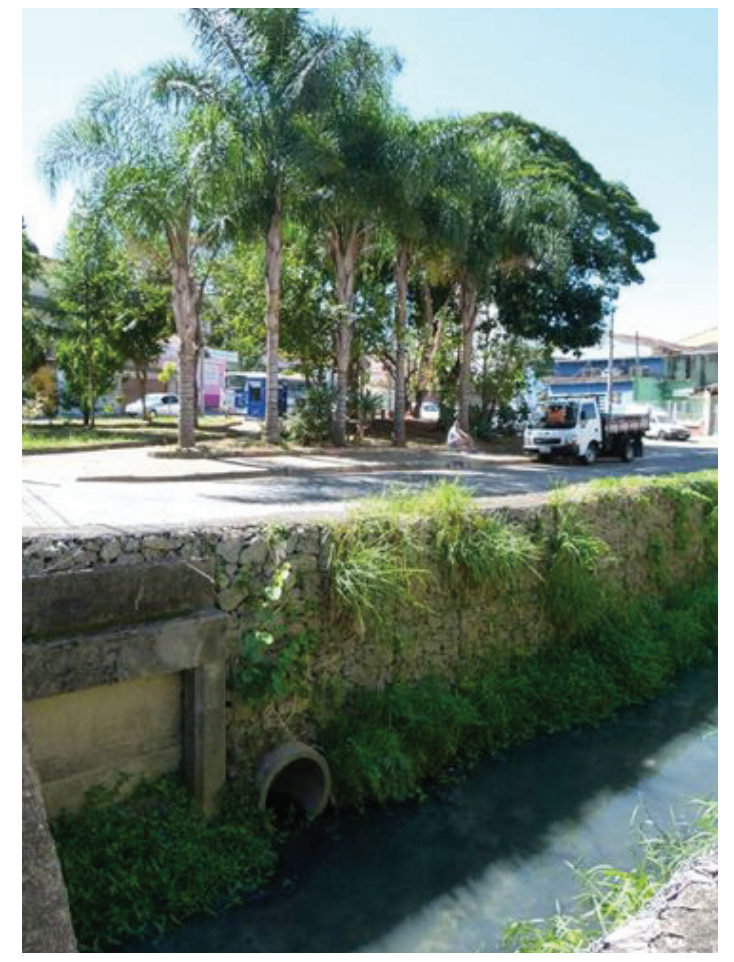

Figura 22 - Córrego junto à Praça Rufus King Lane. Fonte: Imagem das autoras, 2016.

Seguindo pela Av. Daniel Malettini, um grande terreno murado traz a curiosidade do caminho feito pelo curso d'água. A barreira do muro ao longo de toda a quadra é discretamente rompida por a uma estreita abertura através de um antigo guarda-corpo, que sugere a existência de uma ponte no passado (Fig.23). Por ali se revela a passagem do córrego (Fig.24).

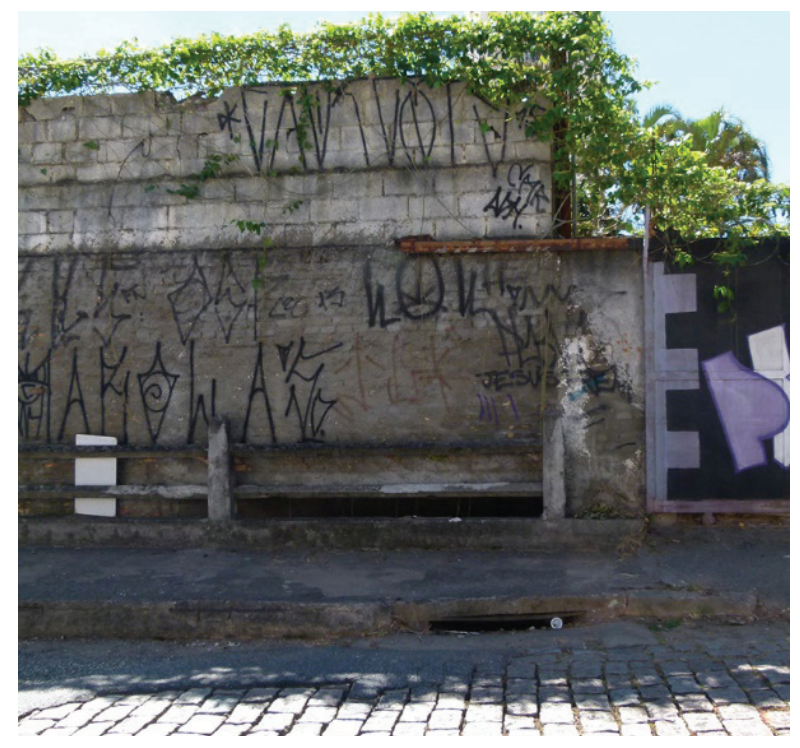

Figura 23 - Guarda-corpo de uma provável ponte indicando um córrego oculto. Fonte: Imagem das autoras, 2016.

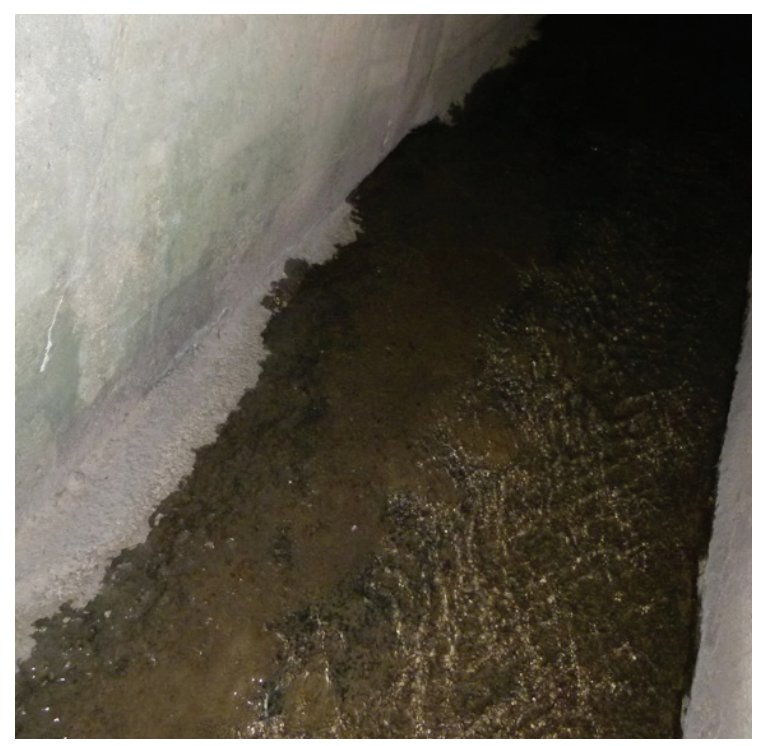

Figura 24 - O córrego aprisionado. Fonte: Imagem das autoras, 2016. 
Continuando o percurso por esta rua chega-se à Av. Água Fria, onde está localizada a Delegacia Geral de Polícia. Por ali o córrego passa canalizado e tamponado e sua presença parece ter sido esquecida na memória das pessoas. Em frente à delegacia, a Praça Novaes Morelli se coloca como importante área verde neste percurso: um local onde pessoas fazem caminhadas ao redor da praça aproveitando o verde que a paisagem revela neste ponto; equipamentos de ginástica ao ar livre trazem usuários à praça, um espaço de convívio bastante agradável. Uma senhora, usuária da praça, revela a ausência de memória do córrego no imaginário da população neste local. Sua presença, evidente no mapa de 1930 (Fig.26), já não é percebida atualmente (Fig.25).

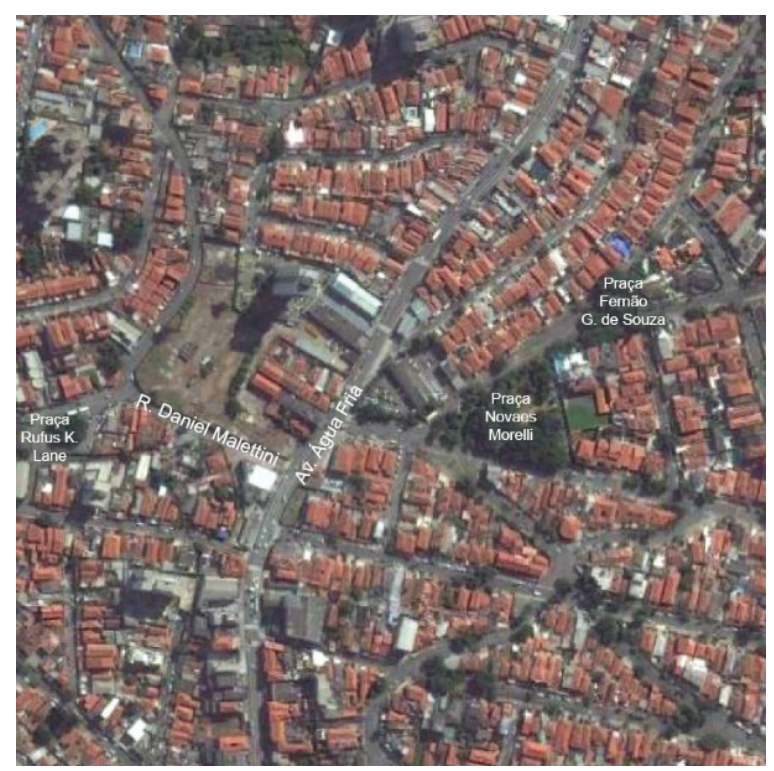

Figura 25 - Fonte: Google Earth, 2016.

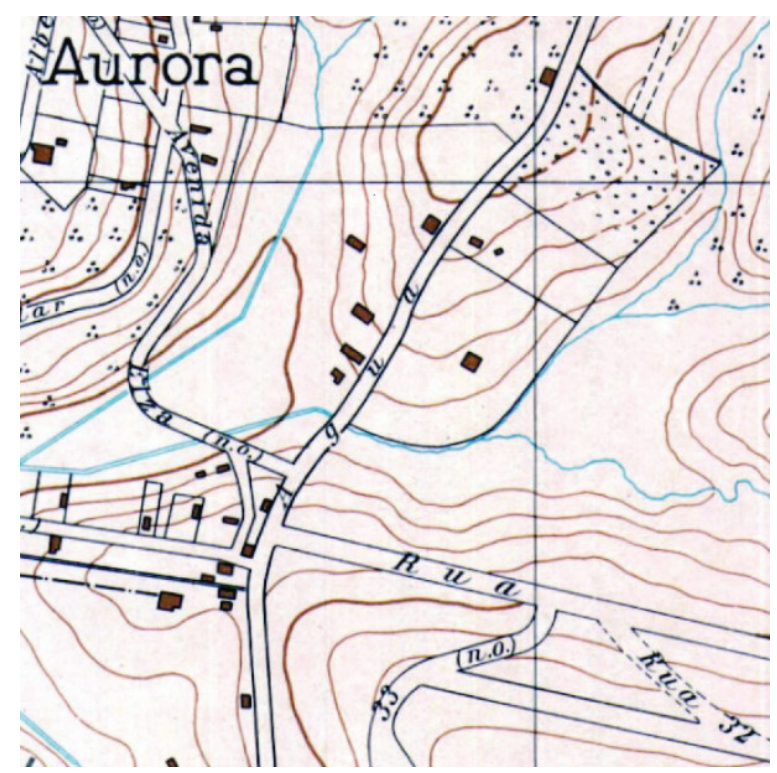

Figura 26 - Fonte: SARA Brasil, 1930.

Um pouco acima, a Praça Fernão Guedes de Souza compõe, juntamente com a Praça Novaes Morelli, um "nó" de áreas verdes públicas costurado pelo caminho das águas, onde braços do córrego descem sob a Rua Careaçu. Através da imagem aérea é possível notar outros dois nós vinculados aos afluentes do córrego: o primeiro formado por dois espaços verdes triangulares residuais bastante arborizados, do lado esquerdo e do lado direito da rua; o segundo, mais acima, onde a rua termina em na grande Praça João de Moraes Setúbal (Fig.27).

Fica evidente, através do mapeamento de 1930 (Fig.28), que a ocupação da região foi conformada sobre a topografia e o arruamento por vezes sobre o caminho das águas. O resultado é a conformação de vias sinuosas, quadras irregulares e áreas verdes residuais, que ocupam as pontas das quadras formadas por bifurcações viárias. 


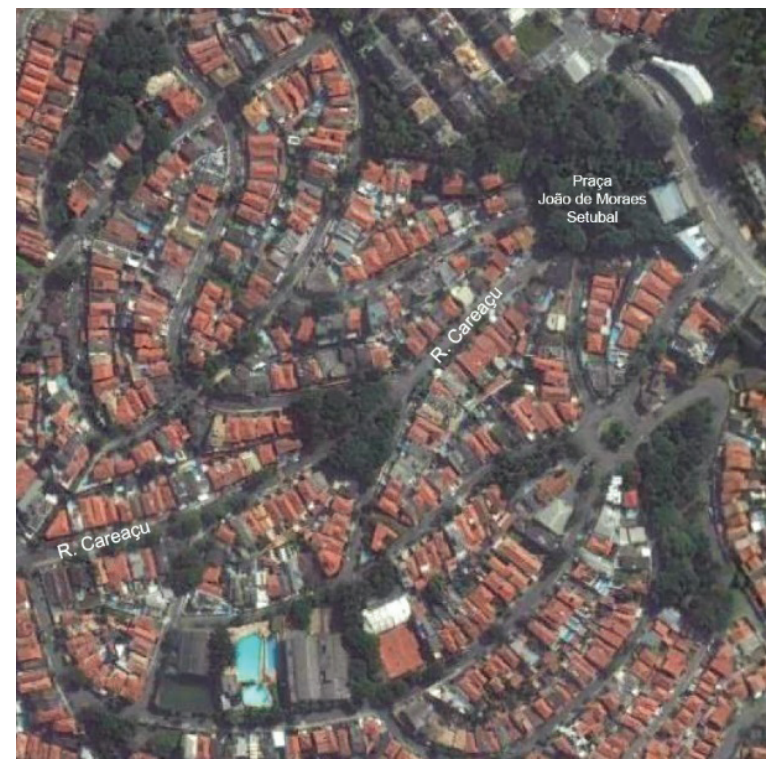

Figura 27 - "Nós" verdes vinculados ao caminho das águas. Fonte: Google Earth 2016.

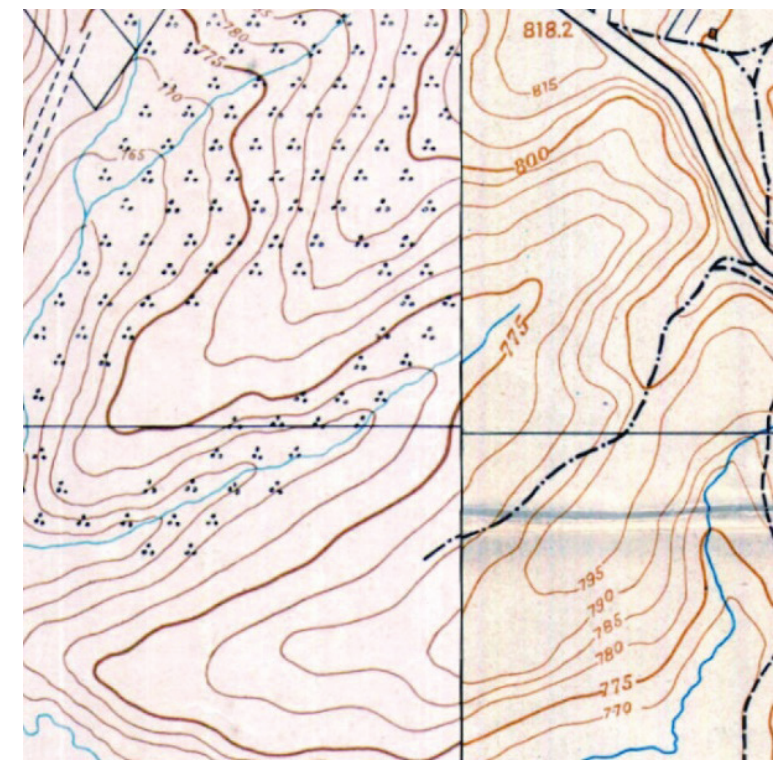

Figura 28 - Topografia e cursos d'água antes da ocupação. Fonte: SARA Brasil, 1930.

\section{Percurso 5 - Córrego Água Fria}

O próximo curso d'água corresponde atualmente ao córrego Água Fria. O início do percurso pela linha deste córrego é logo marcado pela presença de uma área verde na esquina entre a Av. Engenheiro Caetano Álvares e a Rua Larival Géa Sanches (Fig.29 e Fig.30).

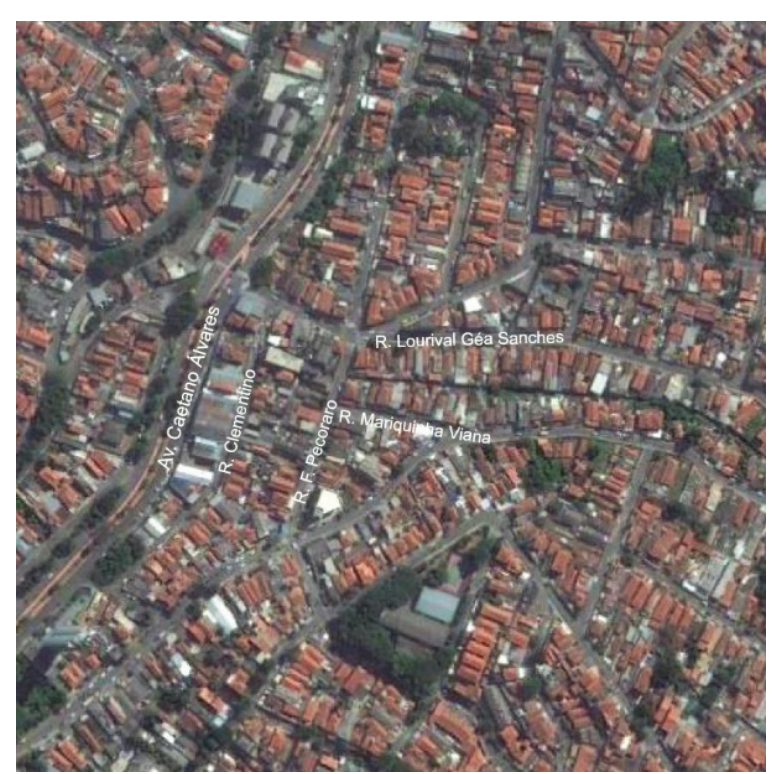

Figura 29 - Fonte: Google Earth, 2016.

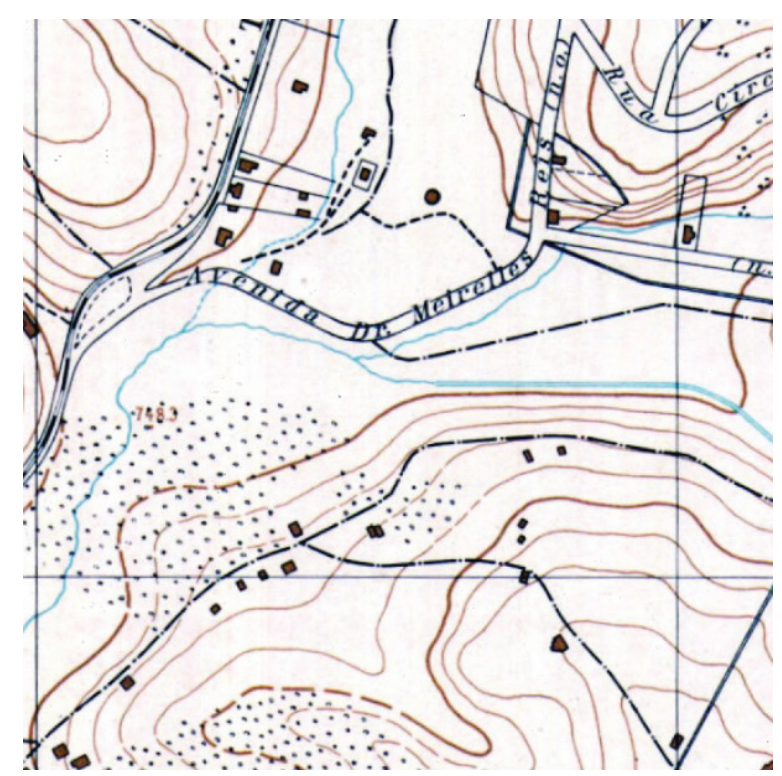

Figura 30 - Fonte: SARA Brasil, 1930. 
Trata-se de um espaço residual, local de acúmulo de lixo e entulho apesar das incansáveis placas indicando multas e penalidades àqueles que os descartarem. Nota-se que esta é uma situação constante em diversos pontos do percurso no qual este tipo de placa se faz presente.

O córrego Água Fria se abre ao lado de um terreno cheio de entulhos (Fig.31 e 32) e, a partir desse local, segue aberto por algumas quadras. A Rua Clementino, paralela à avenida, passa sobre o córrego e dois guardrail metálicos configuram uma pequena ponte, onde é possível observar que, entre esta mesma rua e a Rua Francisco Pecoraro, o córrego segue passando com muito mau cheiro em meio às residências, entre paredes cruas de onde despontam condutores que lançam esgoto ou as águas pluviais diretamente no curso d'água (Fig.33).

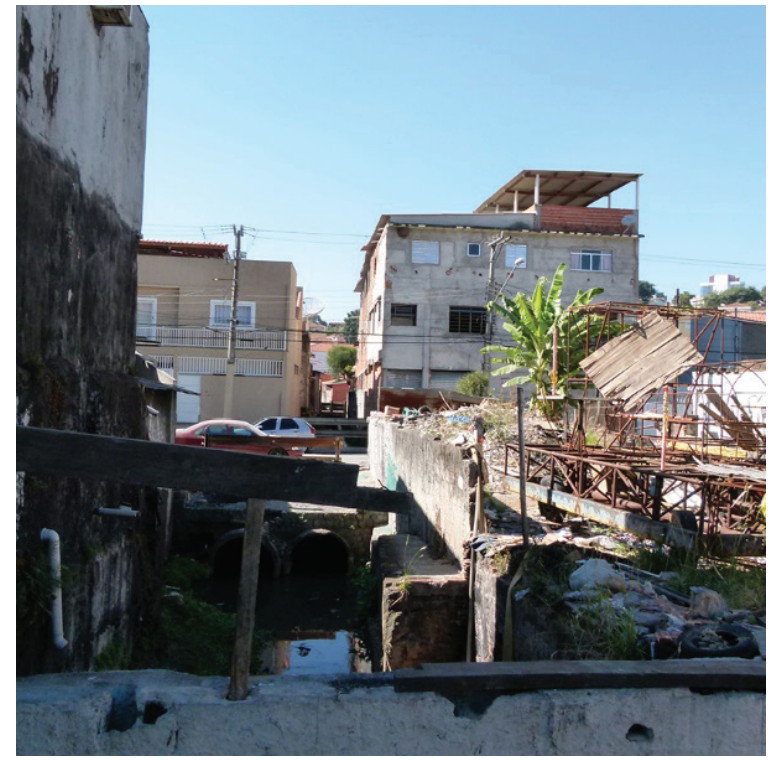

Figura 31 - Córrego da Água Fria visto da Av. Caetano Álvares. Fonte: Imagem das autoras, 2016.

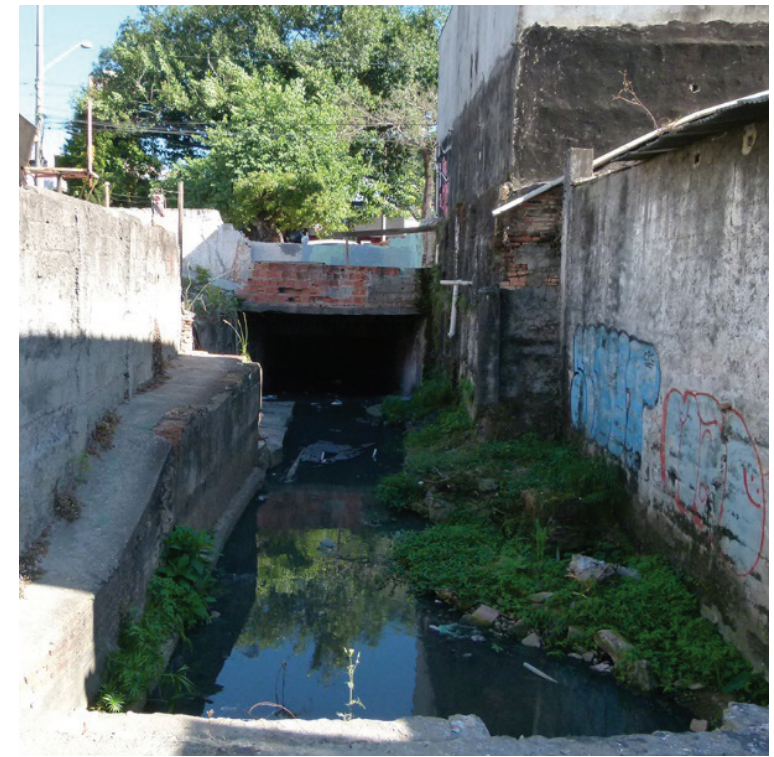

Figura 32 - Córrego da Água Fria visto da Rua Clementino em direção à Av. Caetano Álvares. Fonte: Imagem das autoras, 2016.

A Rua Francisco Pecoraro também passa por cima do córrego Água Fria, onde outros dois guarda-corpos antigos estão presentes, e é possível vislumbrar uma grande tubulação de esgoto que passa pela água do córrego, o qual segue confinado entre muros. Esse é o último ponto onde o córrego está visivelmente acessível.

Apesar do odor, diversas casas têm janelas - que se mantêm fechadas - voltadas para o córrego que vem descendo no interior da extensa quadra, situada entre a Rua Francisco Pecoraro e a Avenida Água Fria (Fig.34), cuja configuração acompanha 
o desenho do curso d'água. Estabelece-se, então, uma relação de afastamento em relação ao córrego, marcado na memória das pessoas que por ali passam como sinônimo de sujeira, dejetos, mau cheiro e doenças. Essa relação com o córrego gera um desejo por parte dos moradores de que ele seja escondido, canalizado e tamponado. Ignora-se muitas vezes a possibilidade de revitalização e recuperação destas áreas.

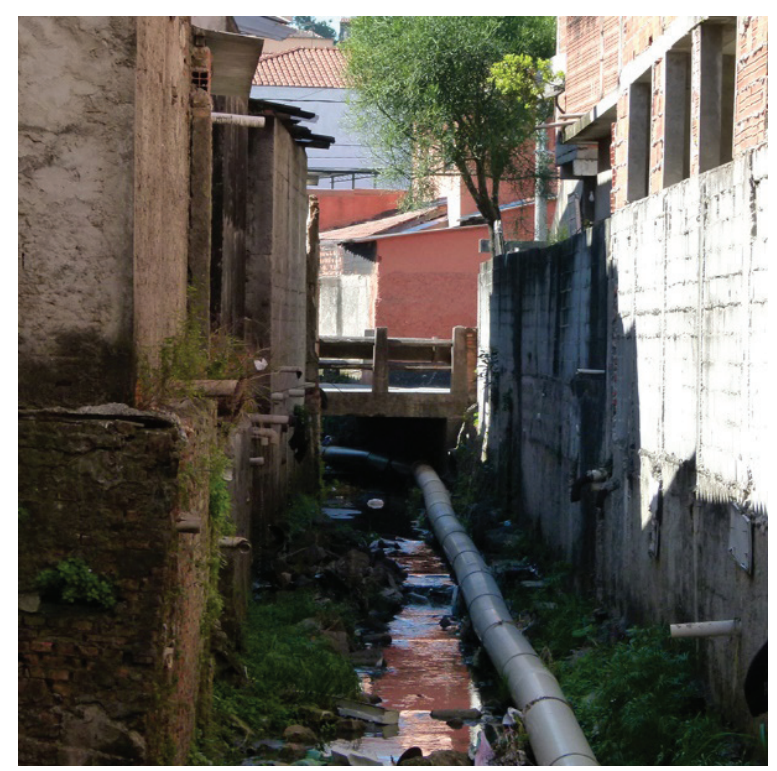

Figura 33 - Córrego da Água Fria visto da R. Clementino em direção à R. Francisco Pecoraro. Fonte: Imagem das autoras, 2016.

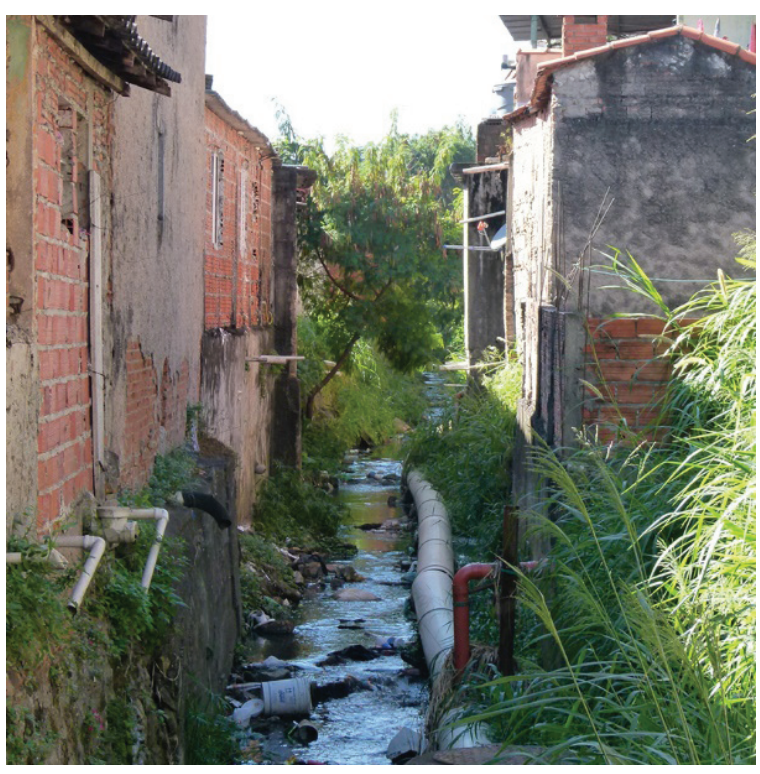

Figura 34 - Córrego da Água Fria visto da R. Francisco Pecoraro em direção à Av. Água Fria. Fonte: Imagem das autoras, 2016.

Na Rua Larival Géa Sanches um pequeno trecho revela a passagem de um veio do córrego anônimo que deságua no córrego Água Fria (Fig.35). Nesse ponto ele está aberto, com vegetação em seu percurso, cortando o quarteirão em direção à Rua Donato Longo (Fig.36). Muito poluído, ele é uma potencial conexão com resquícios de área verde, entretanto hoje cria novamente uma situação de afastamento embora um pequeno grupo de pessoas estivesse no local como que adaptados ao mau cheiro. Este trecho corresponde a um vestígio do traçado original dos corpos d'água da vertente leste, quando o córrego anônimo era um afluente do Água Fria e desaguava nele passando por esse caminho. 


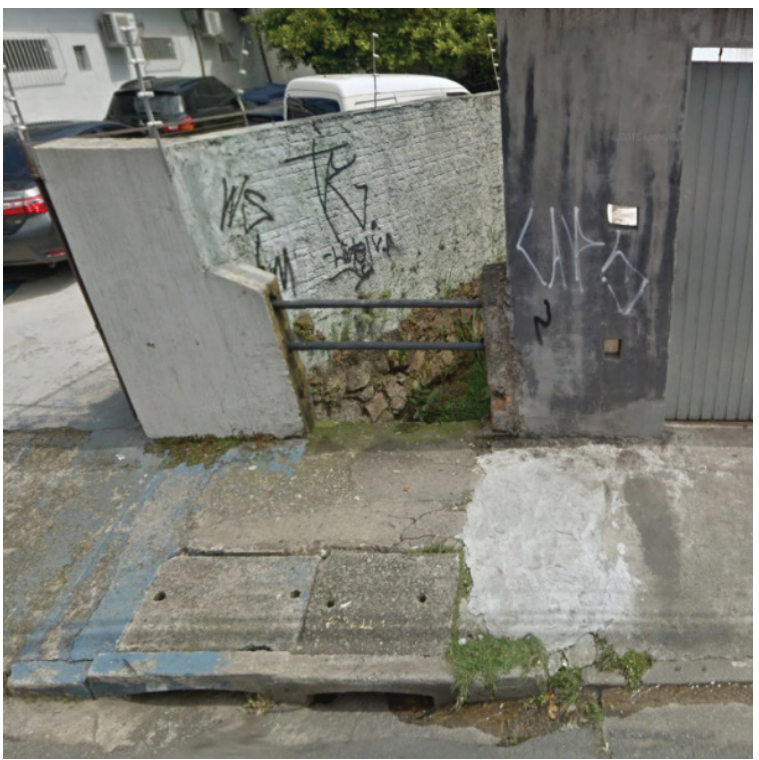

Figura 35 - Veio do córrego anônimo que deságua no córrego da Água Fria visto da R. Larival Géa Sanches. Fonte: Google Street View, 2016.

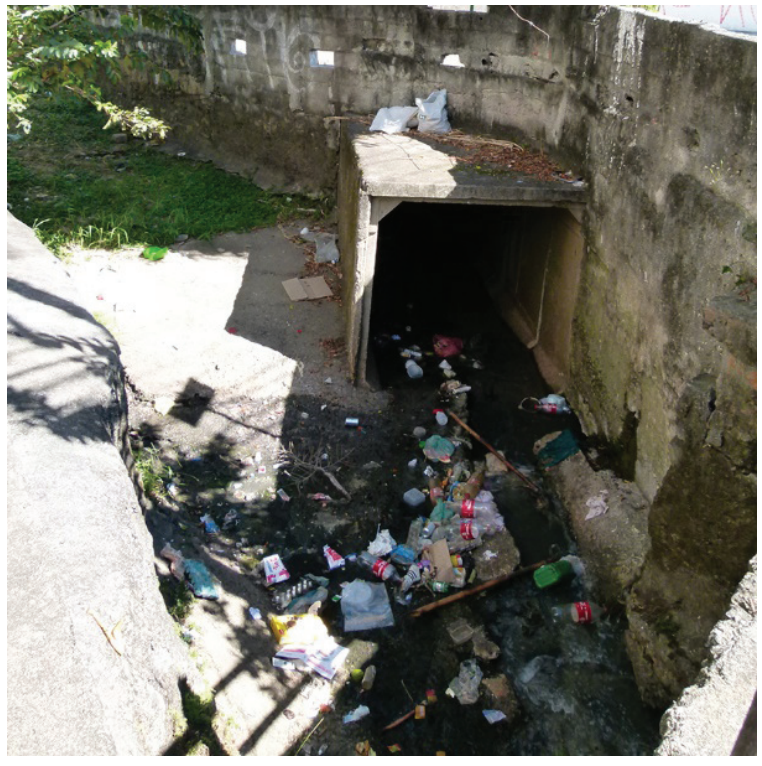

Figura 36 - Veio do córrego anônimo que desagua no córrego Água Fria visto da R. Donato Longo. Fonte: Imagem das autoras, 2016.

Seguindo-se adiante pela Rua Larival Géa Sanches, o córrego que passa em meio ao quarteirão volta a ser canalizado e se esconde na paisagem, com sua presença encoberta pelo asfalto na Av. Água Fria. Continuando o percurso, na Rua Capitão Alberto Mendes Júnior é possível notar a passagem do córrego novamente pelo som. Em um trecho silencioso, com pouca passagem de veículos, a presença do córrego Água Fria é notada entre os dois lados da rua.

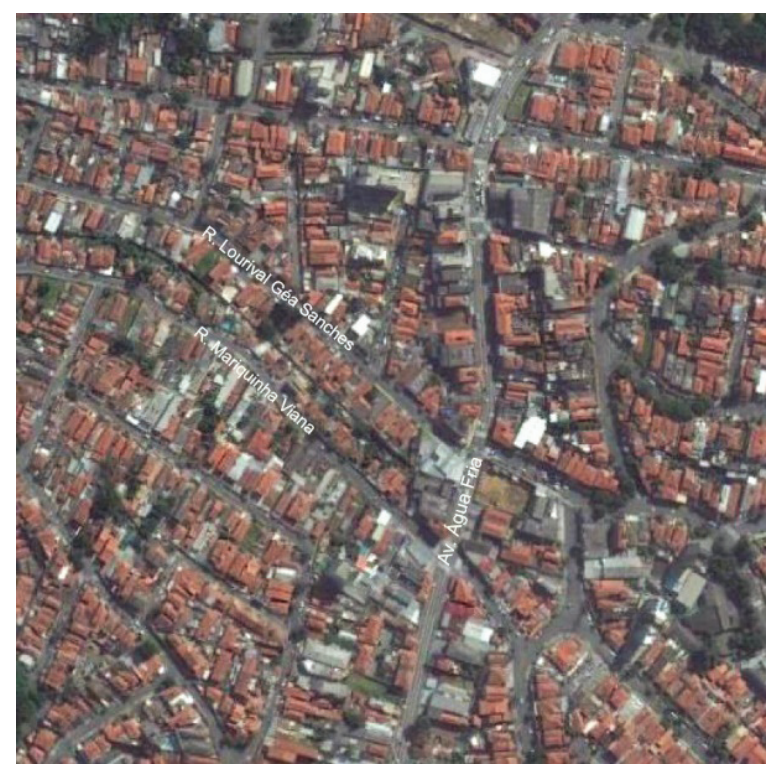

Figura 37 - Fonte: Google Earth, 2016.

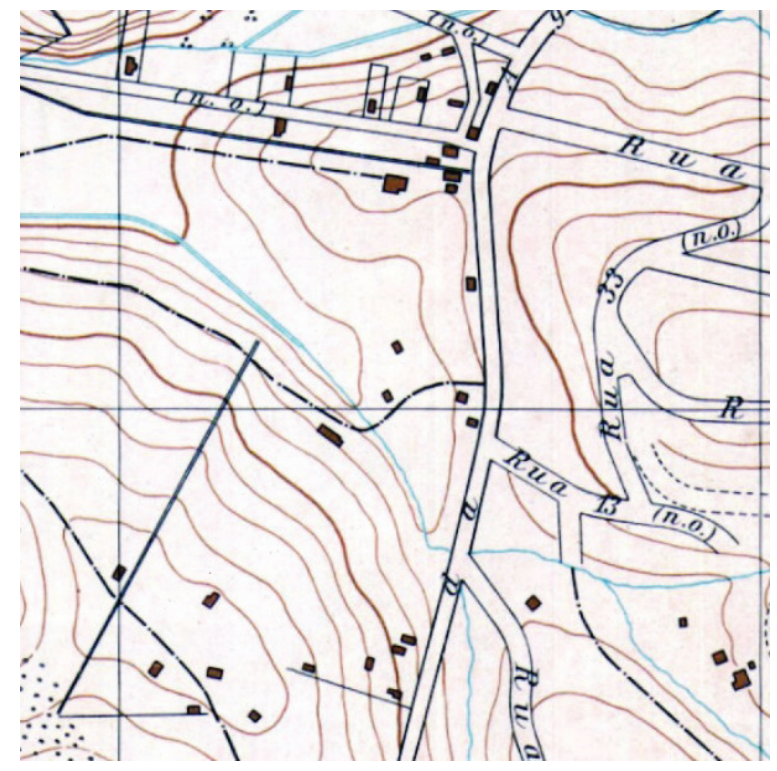

Figura 38 - Fonte: SARA Brasil, 1930. 
Comparando a imagem aérea da área percorrida (Fig.37) com o mapeamento da SARA (Fig.38), é interessante perceber como o arruamento se desenvolveu a partir do desenho do córrego e, conforme dele se afasta, inicia a se retificar sugerindo várias intervenções na topografia para possibilitar a ocupação.

\section{Percurso 6 - Córrego anônimo}

Seguindo pela Avenida Caetano Álvares em direção à Av. Voluntários da Pátria, chega-se à Praça Rubens Fiorani, bastante arborizada e expressiva na área. O córrego, de passagem em meio ao quarteirão conformado pela Rua Voluntários da Pátria, R. Mariquinha Viana e R. Mateus Leme, não se revela diretamente na paisagem. No entanto, a declividade do talude que divide a quadra e a presença de áreas verdes sugere o seu caminho.

Seguindo pela Rua Mateus Leme chega-se até uma pequena rotatória, onde a Rua Maria de Carvalho e Castro leva até a Praça Antônio Zunkeller Leite e na Rua Padre Agostinho Poncet existe uma manifestação artística no pavimento que conecta à Praça Vitoriano Rodrigues Xavier. Continuando, chega-se até a Praça Mateus Leite, um outro espaço verde residual muito íngreme, e a via é bastante sombreada graças à vegetação proveniente desta praça e de um grande terreno ocioso no lado oposto. Ao final da quadra, um maciço verde murado e inacessível indica a provável nascente de um córrego. $\mathrm{O}$ trecho correspondente a esse último percurso está representado nas imagens comparativas abaixo (Fig. 39 e Fig.40).

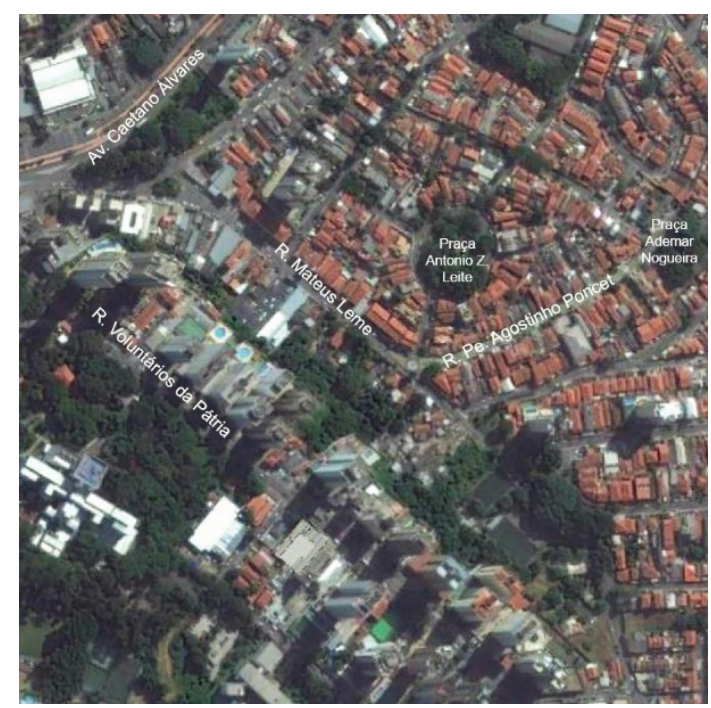

Figura 37 - Fonte: Google Earth, 2016.

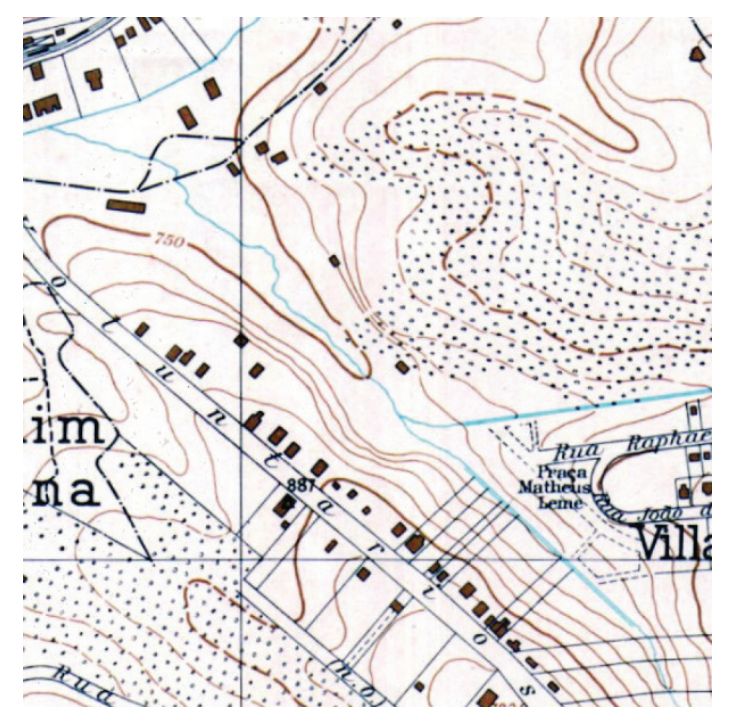

Figura 38 - Fonte: SARA Brasil, 1930. 


\section{NATUREZA E CIDADE: O CONCEITO DE INFRAESTRUTURA VERDE}

Com a industrialização, cada vez mais questões econômicas e tecnológicas conduziram a problemas ambientais que alteraram o papel da natureza na cidade moderna. A separação física e psicológica entre o ambiente urbano e o rural foi se tornando cada vez mais evidente, em um contexto de desaparecimento das áreas verdes e dos cursos d'água das cidades. Os parques urbanos e as praças, quase sempre pautados por questões estéticas e função exclusiva de ócio e recreação, permaneceram na cidade como tentativa resgatar um pouco da natureza. Os rios e córregos, quase sempre canalizados e tamponados, deram lugar a grandes avenidas.

No final do século XX, Michael Hough (1995) já identificava uma distância cada vez maior entre a sociedade e os valores ambientais, com um afastamento entre os processos naturais e a forma física das cidades, onde prevalecem valores estéticos e interesses econômicos. Assim, a cidade exerce grande pressão sobre os sistemas naturais, dependendo deles para a extração de recursos e também para eliminar seus resíduos, em uma relação destrutiva à primeira vista. No entanto, a aproximação entre natureza e cidade, quando vinculada a questões culturais, sociais, econômicas ou de identidade, pode representar a preservação dos recursos naturais. Exemplo é o caso da floresta da Cantareira que, como já mencionado, foi preservada pela ação humana em um momento no qual a regeneração de seus recursos naturais e proteção aos mananciais era fator importante para o projeto urbano e sistemas de abastecimento de água. Assim, Hough (1995) defende que os sistemas naturais operantes na cidade constituem importante base ecológica para o projeto urbano. Para o autor, a integração entre urbanismo e ecologia é algo que precisa ser levado em consideração no processo de planejamento.

Atualmente, muito se fala em infraestrutura verde, sobretudo nas discussões sobre o dilema entre conservação, desenvolvimento e planejamento urbano. O emprego da expressão "infraestrutura verde" sugere algo que deve ser cuidado, uma vez que "infraestrutura" prevê algum manejo. Segundo definição de Benedict e McMahon (2006),

[...] Infraestrutura verde é definida como uma rede interligada de espaço verde que conserva valores e funções do ecossistema natural e fornece os benefícios associados às populações humanas. Em nossa opinião, Infraestrutura verde é o quadro ecológico necessário para a sustentabilidade ambiental, social e econômica - resumindo, é o sistema de sustentabilidade da vida natural da nossa nação. Infraestrutura verde difere das abordagens convencionais 
de planejamento de espaço livre porque ela olha para os valores da conservação e ações associadas com o desenvolvimento da terra, gerenciamento do crescimento e planejamento da construção de infraestruturas. Outras abordagens de conservação são normalmente realizadas isoladas do - ou mesmo em oposição ao - desenvolvimento. (BENEDICT; McMAHON, p.5) ${ }^{1}$

A partir da visão de Benedict e McMahon (2006), compreende-se que a infraestrutura verde é uma conservação que leva em conta os impactos ecológicos e sociais vinculados à expansão urbana. Assim, trata-se de um suporte à vida natural, envolvendo a interligação entre cursos d'água, florestas, parques, caminhos verdes. De acordo com os autores, a infraestrutura verde engloba: reservas, paisagens nativas administradas, terras de trabalho, parques e reservas regionais, parques e áreas naturais da comunidade, conexões da paisagem (landscape linkages), corredores de conservação, caminhos verdes, cinturões verdes, cinturões ecológicos. De modo geral, ela é constituída por matriz - elemento que se autogera -, mancha - como parques e áreas verdes florestadas e corredor, que assume a função de conectividade entre as áreas verdes fragmentadas.

Os planos de infraestrutura verde visam encontrar uma solução que permita ao crescimento e desenvolvimento das cidades conviver junto com a preservação dos recursos naturais. Segundo Benedict e McMahon (2006), cada vez mais as comunidades têm pensado a respeito dos espaços verdes de modo mais sistemático, compreendendo a infraestrutura verde como a 'conservação inteligente' para o século XXI.

A infraestrutura verde, ao envolver questões de gestão, manejo e manutenção - assim como qualquer infraestrutura -, abarca investimentos. Nesse sentido, corre-se o risco de se tornar um termo político, vinculado ao destino das verbas ao verde, tal como ocorre com a infraestrutura viária. No entanto, a ênfase à necessidade de cuidado e manutenção do verde é imprescindível diante do crescimento cada vez maior das cidades. Nesse cenário, a infraestrutura verde representa o resgate da qualidade de vida no ambiente urbano, mitigando os efeitos nocivos da urbanização sem planejamento.

\footnotetext{
1 "[...] green infrastructure is defined as an interconnected network of green space that conserves natural ecosystem values and functions and provides associated benefits to human populations. In our view, green infrastructure is the ecological framework needed for environmental, social and economic sustainability-in short it is our nation's natural life sustaining system. Green infrastructure differs from conventional approaches to open space planning because it looks at conservation values and actions in concert with land development, growth management and built infrastructure planning. Other conservation approaches typically are undertaken in isolation from — or even in opposition to - development." (BENEDICT; McMAHON, p.5)
} 


\section{INFRAESTRUTURA VERDE-AZUL NO MANDAQUI: POSSIBILIDADES DE CONEXÃO}

A infraestrutura verde inserida no meio urbano consolidado compreende não apenas a vegetação, mas inclui também a rede hídrica, compondo uma rede verde-azul. Assim, áreas verdes e água aparecem como elementos complementares e que se protegem na mancha urbana. A conexão entre eles enquanto estruturadores do espaço revela uma força muito maior do que quando considerados isoladamente.

$\mathrm{Na}$ área estudada junto ao córrego Mandaqui e seus afluentes, é latente a conexão entre os cursos d'água e os fragmentos verdes na paisagem. Ao percorrer o caminho das águas, praças e canteiros vão se revelando, porém de forma desagregada. $\mathrm{A}$ possibilidade de conectá-los sugere que integrem uma infraestrutura verde-azul. Essa conexão é fundamental não apenas para os fluxos da água, os ecossistemas e a biodiversidade, mas também para a qualidade de vida humana.

Planejar e manter uma infraestrutura verde-azul pode trazer inúmeros benefícios de caráter ambiental e social. A recuperação e tratamento dos cursos d'água, além de criar um ambiente mais saudável ao convívio humano, permite reativar serviços ambientais, como a melhoria da drenagem e redução de enchentes. Em vários pontos junto aos veios d'água e córregos afluentes do Mandaqui, uma intervenção nesse sentido de regeneração possibilitaria um novo olhar sobre a rede hídrica presente no espaço urbano consolidado. $\mathrm{O}$ atual afastamento - expresso pelo despejo de resíduos e esgoto sem tratamento e desejo de canalização e tamponamento - entre os cursos d'água e as pessoas poderia ser revertido em uma aproximação benéfica em todos os sentidos. Essa reconciliação possibilita ao homem se apropriar, defender e preservar os córregos e veios d'água, compreendendo-os como fundamentais à sua própria vida.

Para efetivar o resgate de tais cursos d'água e conscientizar os habitantes locais, é essencial que o trabalho de recuperação seja feito simultaneamente a restauração dos espaços verdes, possibilitando que tais espaços agreguem fortes valores sociais vinculados ao conjunto. Os espaços verdes residuais poderiam tornar-se espaços com alguma função social; os cursos d'água poderiam ter intervenções paisagísticas; espaços contíguos aos córregos poderiam configurar praças. Todos estes espaços, praças, parques e reservas - propondo-se inclusive uma escala maior que se estenda até a Floresta da Cantareira -, poderiam ser conectados por ruas verdes, onde o fluxo 
do pedestre seria prioritário. Os fragmentos permeáveis e vegetados dispersos pela mancha urbana poderiam, interligados através de estratégias de infraestrutura verde, reestabelecer os processos naturais no espaço urbano.

\section{CONSIDERAÇÕES FINAIS}

Os processos de crescimento e desenvolvimento que incidem sobre a cidade trazem consigo riscos à sobrevivência e preservação de recursos hídricos e áreas verdes no espaço urbano. O padrão de descontinuidade apresentado entre os espaços verdes e a negligência em relação aos corpos d'água no alto da bacia do Mandaqui pode ser observado em outras regiões de São Paulo. Os resquícios verdes e azuis presentes no tecido urbano, como resultado da expansão urbana e crescente valorização do automóvel, têm sua presença dissimulada no cotidiano das pessoas. Fragmentos de áreas verdes se revelam em meio à paisagem consolidada e são, quase sempre, conectados pela rede hídrica oculta. Muitos córregos foram canalizados e tamponados, mas sua presença vem à tona em alguns pontos, revelando uma identidade e história local escondida pela ação humana.

O reconhecimento desses fragmentos de áreas verdes e córregos ocultos na cidade é um primeiro passo para sua preservação. A ideia sistêmica de conectá-los através de uma infraestrutura verde e azul aparece como potencial possibilidade para resgatar e preservar valores ecossistêmicos naturais. Dessa forma, a proteção dos processos ecológicos e a consequente melhoria da qualidade de vida dos habitantes das cidades atuam de forma a gerar uma melhor e mais sustentável integração da natureza no espaço urbano.

\section{REFERÊNCIAS}

AB'SABER, Aziz Nacib. Geomorfologia do Sítio Urbano de São Paulo. Cotia, SP: Ateliê Editorial, 2007.

BENEDICT, Mark A.; McMAHON, Edward T. Green Infrastructure: Smart Conservation for the 21st Century. Sprawl Watch Clearinghouse Monograph Series. Washington, 2006. Disponível em: <http://www.greeninfrastructure.net/>. Acesso em: 12 de maio de 2016. 
CABRAL, Arthur Simões Caetano. Os córregos ocultos e seus resquícios nos espaços livres urbanos: Os afluentes do córrego Mandaqui. São Paulo, ano 15, n. 177.03, Vitruvius, fev. 2015. Disponível em: <http://www.vitruvius.com.br/revistas/ read/arquitextos/15.177/5479>. Acesso em 12 de maio de 2016.

DERSA. Resposta da DERSA à matéria "Ambientalistas tentam barrar financiamento do trecho Norte do Rodoanel". In: CALIXTO, Bruno. Dersa: obras do Rodoanel atendem às exigências ambientais. Blog do meio ambiente, Época, edição digital, 24 abr. 2013. Disponível em: <http://colunas.revistaepoca.globo.com/planeta/2013/04/24/dersa-obras-do-rodoanel-atendem-as-exigencias-ambientais/>. Acesso em: 20 de maio de 2016.

HERLING, Tereza. A floresta em São Paulo, a cidade na Cantareira: fronteiras em transformação. 2002. 222 p. Tese (Doutorado) - Faculdade de Arquitetura e Urbanismo, Universidade de São Paulo, São Paulo, 2002.

HOUGH, Michael. Ecología urbana: una base para la remodelación de las ciudades. In: HOUGH, Michael. Naturaleza y Ciudad. Planificación Urbana y Procesos Ecológicos. Barcelona: Gustavo Gili, 1998 (1995).

LANGENBUCH, Jurgen Richard. A estruturação da Grande São Paulo. 1971. 527 p. Tese (Doutorado) - Faculdade de Filosofia, Ciências e Letras de Rio Claro, UNICAMP, Rio Claro, 1971.

MONTEIRO JÚNIOR, Laércio. Infraestruturas urbanas: uma contribuição ao estudo da drenagem em São Paulo. 2011. 278 p. Tese (Mestrado) - Faculdade de Arquitetura e Urbanismo, Universidade de São Paulo, São Paulo, 2011.

SABESP - Companhia de Saneamento Básico do Estado de São Paulo. Redes condominiais de alta complexidade realizada pelo Programa Córrego Limpo e Programa Saneamento para Todos: Obras e ações sociais, s.d. Disponível em: <http://www.abessp.org.br/arquivos/corrego_limpo_condominial_rev.pdf>. Acesso em: 20 de maio de 2016.

TZORTZIS, Patricia Storopoli; KNIESS, Claudia Terezinha. Programa de despoluição de córregos: Programa Córrego Limpo. In: SIMPÓSIO INTERNACIONAL DE GESTÃO DE PROJETOS, INOVAÇÃO E SUSTENTABILIDADE, 4., 2015, São Paulo. Anais... . São Paulo: Singep, 2015. p. 1 - 11. 